\title{
Supply Chain Finance: from traditional to supply chain credit rating
}

\author{
Antonella Moretto*, Laura Grassi, Federico Caniato, Marco Giorgino, Stefano Ronchi \\ School of Management, Politecnico di Milano \\ *corresponding author: antonella.moretto@polimi.it
}

\begin{abstract}
Traditional credit rating models, adopted by financial institutions to assess the credit risk of a company, adopt a purely financial perspective, and often fail to properly assess small and medium enterprises. On the other hand, buyers usually assess suppliers by means of comprehensive vendor ratings, considering a broad range of operational performance. This paper investigates whether financial and vendor ratings can be integrated into a supply chain credit rating model that jointly considers financial indicators of the supplier and its operational evaluation provided by buyers; the paper also investigates the benefits and the challenges of such a model for all the stakeholders involved (buyers, suppliers, financial institutions, and technology providers), adopting the lenses of the stakeholder theory. We adopted both multiple case studies and an iterative focus group, involving representatives from suppliers, buyers, financial institutions, and technology providers. The results confirm the potential value of such an integrated rating, mainly for strategic suppliers, showing the expected benefits for all stakeholders and highlighting the potential challenges to face.
\end{abstract}

Keywords: Supply Chain Finance; Financial Rating; Vendor Rating, Supply Chain Performance; Credit Risk

Full reference: Moretto, A., Grassi, L., Caniato, F., Giorgino, M., \& Ronchi, S. (2019). "Supply chain finance: From traditional to supply chain credit rating". Journal of Purchasing and Supply Management, Vol. 25, No. 2, pp. 197-217.

Author's post-print released with a Creative Commons Attribution Non-Commercial No Derivatives License 


\section{Introduction}

The 2008 financial crisis caused a dramatic reduction in the concession of new loans to companies; at the same time, relevant growth in the interest charged by banks was reported (Ivashina and Scharfstein, 2010). These phenomena were caused by a strong increase in perceived corporate risk, as depicted by corporate credit ratings. In fact, the post-crisis distribution of corporate credit ratings among the most relevant rating agencies showed a considerable decrease in the number of "investment grade" non-financial corporations, as well as a considerable increase in worse ratings (Chava and Purnandam, 2011). The worsening of credit ratings has a direct impact on bank lending, especially under the Basel requirements (BIS, 2011). Further, the increased perception of credit risk and higher capital requirements driven by Basel II led to an overall increase in bank risk aversion, which led to a restriction of trade finance facilities toward more risky parties (Asmundson et al., 2011).

In such a contest, liquidity-scarce companies tried to compensate for the contraction in bank lending through increased access to trade credit, i.e., increasing payment terms toward suppliers and/or reducing settlement terms with customers, with the risk of triggering liquidity shortages along the chain (Klapper and Randall, 2011). These liquidity shortages have a clear supply chain effect: late payments, and even worse defaults, propagate from a company to its suppliers (Raddatz, 2010). In one case out of four, a liquidity shock (for example, related to a customer default) is transferred to the upstream actors along the supply chain (Boissay and Gropp, 2007).

This context of cash shortage contributed greatly to the development of solutions for interorganizational working capital management. Among these, one of the most important approaches is supply chain finance (SCF), which aims to optimize financial flows at an interorganizational level (Hofmann, 2005; Pfohl and Gomm, 2009) through solutions implemented by financial institutions or technological providers (Chen and $\mathrm{Hu}, 2011$; Lamoureux and Evans, 2011). SCF consists of a broad range of solutions and approaches (Gelsomino et al., 2016a), but all share a common feature: supply chain characteristics, such as the quality of relationships between supply chain players and with financial institutions, greatly affect the successful adoption of SCF solutions (Wuttke et al., 2013). For example, reverse factoring (i.e., one of the most common SCF solutions in which a buyer company facilitates early payment of its trade credit obligations to suppliers) is based on the assessment of buyer-supplier relationships to finance a risky supplier, thanks to its buyer creditworthiness (Caniato et al., 2016).

However, traditional financial credit rating models do not adopt the SCF perspective: they are mainly based on the financial characteristics of the single company, such as the level of their debt and their profitability (Edwards, 1997; Wood, 1981). In fact, these financial performance metrics are somehow also impacted by operational performance, but several issues limit their effectiveness to properly assess credit ratings. On the one hand, financial data usually refer to the past since they are available just several months after the end of the year (in particular for SMEs, which do not publish quarterly results). Second, financial data are quite slow in reporting changes in companies' actual operational performance, as the impact of operations and supply chain choices on financial performance is indirect and delayed. Third, financial data are rarely available and reliable for small companies. Finally, these models hardly take into consideration supply chain information or an inter-organizational perspective, such as the existence of strategic relationships between buyers and suppliers or the operational performance of the supplier as perceived by the buyer (Edwards, 1997; Wood, 1981). For these reasons, financial credit rating models are unable to completely and quickly assess the real risk of a company, in particular a SME. 
Within supply chain relationships, buyers instead usually perform structured and frequent evaluations of the operational performance of their suppliers, by means of what is often referred to as vendor rating (Luzzini et al. 2014). These models may also include some financial information, usually obtained from information providers, but are mainly aimed at monitoring the supply risk. These data can be very quick in identifying changes in the normal performance of a supplier. An unexpected change in the trend of vendor rating performance for a supplier might be an alert for a major problem in overall supplier performance. These data are not only highly valuable for buyers, but have a great potential interest for financial institutions, as they could allow a better and faster assessment of the credit risk of suppliers, in particular SMEs. However, vendor rating information is usually not shared with financial institutions.

There have been attempts to also consider operations and supply chain information to assess the risk of a company (e.g., Bendig et al., 2017), and financial institutions are looking for new advanced analytics to detect potential business failures (Zhao et al., 2015). While preliminary studies have been done, a true supply chain-oriented credit rating model to be used by financial institutions is still missing (Wang, 2010; Su and Lu, 2015). Existing models are mainly used by buyers for their own purpose, without sharing data with external actors and in particular with financial institutions. A supply chain credit rating model, i.e., a model that combines financial data and supply chain data in a comprehensive way, would overcome the limitations of traditional credit rating models.

Therefore, the objective of this paper is to investigate whether it would be possible to integrate the traditional financial credit rating with the vendor rating performed by buyers into a supply chain credit rating model useful for buyers, suppliers, financial institutions and technology providers. We define a supply chain credit rating model as one that takes into account information on both the financial performance of a company (in particular a supplier) and its supply chain relationships and performance, as perceived by its buyers, with the purpose of increasing the timeliness and responsiveness in predicting future performance, and therefore credit risk.

To achieve this goal, we adopt the theoretical lens of stakeholder theory (Freeman et al. 2010), as we consider all the stakeholders who need to be involved in the definition of a supply chain credit rating, to understand their willingness to contribute and the potential value that they could obtain. This theoretical lens was selected because the main limitations of existing models pertain to the inability to show the value for different stakeholders (e.g., financial institutions developing the rating and lending money, the buyer company providing the data, the supplier company being object of the evaluation and borrowing money, technology providers offering tools and connectivity to gather, share, and analyze data both along the supply chain and with the financial system). From this perspective, we conducted both multiple case studies and an iterative focus group involving industrial companies (buyers and suppliers), financial institutions, and technology providers.

In the following sections, we present first a literature review on the main concepts investigated this work, i.e., financial rating, vendor rating, and stakeholder theory. Subsequently, we formulate our research questions and framework and present our methodology. We then present the results of our investigation and discuss them, formulating propositions. Finally, the contributions and limitations of our study are presented in the concluding section.

\section{Literature review}

\section{Financial rating}


A financial rating is an independent and fair judgment of the financial situation of a company to support the investment choices of both institutional and retail investors. A financial rating is mainly provided by rating agencies: three main agencies (i.e. Moody's, Standard and Poor's, and Fitch) are leaders in the market worldwide, as they likely accumulated more reputational capital by providing valuable recommendations (Partnoy, 1999). However, other agencies exist and operate at a national, regional, or global level. For example, as of May 1st, 2018, 45 agencies have been registered or certified by the European Securities and Markets Authority (ESMA, 2018 www.esma.europa.eu).

Rating agencies take into account the macroeconomic environment, the corporate governance and the business strategy, the competitive positioning, the risk management, and the financial profile. The traditional approach, known as the 5Cs, considers capital (value of capital assets), collateral (cash and assets to secure a loan), character (financial history), capacity (ability to generate sales revenue), and condition (external circumstances that influence the repayment ability) (Edwards, 1997; Wood, 1981).

A strong increase in the credit risk estimates, mainly measured through external ratings formulated by rating agencies (Basel, 2004) and financial institutions, is directly related to the dramatic reduction of access to new loans observed in the last decade in Europe. For this reason, the process and criteria used by the rating agencies are strongly debated. Meanwhile, even though highly criticized, financial markets still rely on them (Purda, 2011). In particular, three main criticisms have been made regarding credit ratings.

The first criticism involves the process through which the rating agencies assess the rating of a company. In fact, rating agencies rarely publish their methodology as well as the main variables through which they are assessing the financial health of a company. Thereby, due to some opacity in the judgment process, as well as some possible conflicts of interests, both investors and regulators are aware of the need for a common measure of risk, which should be more accurate and free of conflicts of interest (Baklanova, 2009). According to Gibson et al. (2014), the rating process could even be related to irrational behavior.

The second criticism is the timing with which the agencies provide a rating to a company. There is some evidence that the change in the rating of a company is quite slow (Altman and Rijken, 2004) and thus the market clearly anticipates the change of the rating of a company (Kenjegaliev et al., 2016).

The third involves the "issuer pay" model. In the 1970s, a change in the agencies' revenue model switched the cost of the rating to the same companies interested in receiving a rating (White, 2010).

Rating agencies are not the only financial institutions formulating financial ratings. In the late 1990s, banks started using internal ratings to assess the credit risk of companies (English and Nelson, 1998), which are now at the basis of commercial lending. The variables considered, the grades, and the scale can vary among banks (Treacy and Carey, 2000). Furthermore, banks do not use solely a mechanical approach, as there are at times factors that are highly linked to the specificities of the business, the geographical area, and the lifecycle of the firm (Treacy and Carey, 2000). Under the Basel Agreements, banks generally use an internal rating-based system (IRB). The approach takes into consideration the probability of default (PD), the loss given default (LGD), the exposure at default (EAD), and the maturity of the exposure (M) (Basel Committee, 2001).

These parameters are always considered when approving a loan to a company. As a consequence, having a high probability of default, a high loss in the case of default, a high 
exposure at default, and a high maturity will limit the possibility for a company of receiving the required amount and will increase the cost of borrowing. Several previous works focused the analysis on the IRB system in place and the credit risk of the loan portfolio of the bank (e.g., Jacobson et al., 2006).

In comparison to rating agencies, banks' internal ratings have a short-term revision and are not subject to a fee directly charged to the assessed company, also because the rating is not publicly disclosed. However, in assessing the rating of a company, both agencies and banks consider mainly financial quantitative factors (Tracy and Carey, 2000), such as capital structure, profitability, and liquidity (Grunert et al., 2005), as they are indisputably more standardized and easily measurable. Some attempts to include qualitative factors have been made (e.g., Brunner et al., 2000), considering, for example, management experience and business and industry information, but without going into great depth (Grunert et al., 2005).

On the contrary, literature on the innovation in models, parameters, and perimeters of analysis is scarcer. Among such literature, Grunert et al. (2005; p. 528) state "whereas the relevance of financial factors for rating purposes is widely accepted, the consideration of non-financial factors is equally beyond controversy but it has often only holistically been justified. [...] the combined use of financial and non-financial factors leads to a significantly more accurate default prediction than the single use of financial or non-financial factors." Lehmann (2003) recognizes the importance of including qualitative information in credit ratings to increase reliability, sustaining also that little research has been made on the role of "soft factors." Recently, Su and Lu (2015) stated that taking into account a supply chain perspective in the credit risk assessment could lead to a more accurate and reliable evaluation. Indeed, taking the firm as a single independent entity, instead of a part of a supply chain, the risk assessed could be overestimated. In addition, Zhao et al. (2015; p.1683) state that "financial institutions can effectively leverage the external information sources through "unconventional" predictor variables in order to reduce the credit risks associated with business failure of SCF clients."

Therefore, the financial rating model, based only on quantitative data, needs to be enriched with qualitative variables and a broader supply chain perspective, especially to improve the capability to predict the company's probability of default. However, how such rating is built, and what its potential benefits are, remain to be understood.

\section{Vendor rating}

Considering the suggestions of $\mathrm{Su}$ and $\mathrm{Lu}$ (2015) about the use of supply chain data to improve credit risk assessment, we investigated the literature on vendor rating. Vendor rating is not a new concept, as it dates back to the 1960s (Parthiban et al., 2013). It is the last phase of the more general supplier evaluation process, after supplier qualification and selection, and is carried out for suppliers that are receiving purchase orders. It can be defined as a collection of KPIs, ranging from quality to service level, that typically involves several departments within an organization (Luzzini et al., 2014).

Vendor rating is a core process of supplier management (Lasch and Janker, 2013), and its importance for a company is clear: neglecting a proper evaluation of suppliers is likely to be a costly error (Carter and Narasimhan, 1996). According to Carter et al. (2010), the current literature mainly focuses on two streams: suitable KPIs for rating suppliers, and models and methods to implement an effective vendor rating. For the former, contributions tend to focus mainly on providing the classification of possible sets of indicators (e.g., Humphreys, 2003), whereas other studies have investigated the importance of choosing indicators according to a set of drivers, specific to the situation/company. The first stream has greatly evolved over time, 
moving from a strong focus on cutting costs (i.e., focusing mainly on vendors' product price) to more complex rating systems, including product quality, delivery time, and performance history (Weber et al., 1991). In fact, factors like quality, service level, and cycle time tend today to overcome price in terms of importance in supplier evaluation (Wilson, 1994; Sharland et al., 2003). Moreover, vendor rating system criteria include managerial and technological capabilities, flexibility, innovation, financial position, and sustainability (Ho et al., 2010; Punniyamoorthy et al., 2011). The literature on the definition of KPIs for supplier evaluation is now mature, with several contributions presenting sets of pre-defined indicators for different contexts (Humphreys et al., 2007; Huang and Keskar, 2007). The proliferation of criteria for rating suppliers led to the development of multi-criteria models that return a single rating for each supplier. Thereby, related to the second literature stream, several methodologies have been proposed: the most common include the analytical hierarchy process (e.g., Sivakumar et al., 2015), data envelopment analysis (e.g., Ho et al., 2010), structural equation modelling, linear and non-linear programming ( $\mathrm{Ng}, 2008$; Talluri, 2002), and several others.

In conclusion, the literature on vendor ratings has reached a considerable level of maturity, both in terms of indicators upon which to score suppliers and methodology to process data into a single final rating. They are quite well adopted among structured companies, with the support of dedicated advanced software platforms (Luzzini et al., 2014). In this vein, in recent years the focus of vendor rating literature shifted from methods and variables to some more innovative aspects, such as the organizational and relational issues related to the entire life cycle of supplier evaluation (Maestrini et al., 2017) and the integration of supply chain variables into financial ratings, with the purpose of improving the creditworthiness evaluation ( $\mathrm{Su}$ and $\mathrm{Lu}, 2015)$ as well as default probability assessment (Zhao et al., 2015). These initial integration attempts address a potentially valuable new area of adoption of vendor rating data. However, a vendor rating is usually developed and managed autonomously by companies to evaluate the supply base for internal purposes only, the results are seldom shared with suppliers, and never shared or published with third parties (Luzzini et al., 2014). Therefore, the considerable body of information included into existing vendor rating systems is not yet exploited for assessing credit rating.

\section{Stakeholder theory}

Considering that a supply chain is actually a network of multiple companies and actors, and that we are interested in investigating not only the relationships within a supply chain, but also with the financial system, our primary theoretical foundation is stakeholder theory. Stakeholder theory considers the various internal and external stakeholders of a firm, assuming that no stakeholder stands alone in the process of value creation (Freeman et al., 2010). Stakeholder theory fits well with a supply chain perspective, since benefits such as increased legitimacy, environmental stability, trust, and cooperation (Jones, 1995; Heugens et al., 2002; Meyer and Rowan, 1977; Suchman, 1995; Laplume et al., 2008) are shared among the interconnected companies on the basis of their relative contribution (Phillips et al., 2003).

A shared definition of who can be considered a relevant stakeholder in any supply chain is still lacking. According to Stainer and Stainer (1998), there are eight different categories of stakeholders together with their expectations: shareholders, suppliers, creditors, employees, customers, competitors, government, and society. Freeman et al. (2010) and Busse et al. (2017b) instead identify 11 categories, adding financial institutions, managers, unions, and activist groups, while creditors should be part of one of the former; Donaldson and Preston (1995) include also political groups.

The heterogeneity in definitions of stakeholders may be based on who is perceived as being affected by the issue at stake. Considering credit risk assessment, and following Tantalo and 
Priem (2016), some of the former stakeholders are not directly involved: employees, unions, activist groups, society, and competitors. Therefore, the main stakeholders considered in our research are:

- Suppliers: companies whose credit risk needs to be assessed

- Buyers: companies buying from suppliers and assessing their operational performance through vendor rating systems

- Financial institutions: institutions developing the credit rating and lending money (banks, factors or rating agencies)

- Technology providers: information and communication technology companies, who offer tools and connectivity to gather, analyze, and share data both within the supply chain (e.g., vendor rating systems) and with the financial system (e.g., financial ratings)

\section{Research objectives and research framework}

\section{Research objectives}

The literature review showed that nowadays credit risk assessment performed by banks and rating agencies is mainly focused on financial information only (Tracy and Carey, 2000). Some authors, however, have highlighted the importance of also including qualitative information. Among them, Grunert et al. (2005) highlight that, while the relevance of financial factors is widely recognized, the importance of soft factors (e.g., managerial competences) has been justified only holistically. These authors also state that the combined use of both financial and non-financial factors leads to more accurate default prediction than the employment of financial information only. Moreover, Lehman (2003) recognizes the importance of qualitative information in credit rating to increase reliability, claiming that only little research has been done on the role of soft factors, such as management quality or market position, in internal financial rating systems. Little research is available about the potential improvement that qualitative information can provide in terms of the reliability and effectiveness of internal rating systems. More precisely, supply chain information is not currently taken into account in the credit rating of companies. Indeed, $\mathrm{Su}$ and $\mathrm{Lu}$ (2015) sustain that it is fundamental to consider the risk condition of all the companies in the supply chain when assessing the whole chain credit risk to enhance accuracy and reliability.

Even if the need of assuming a supply chain perspective has been identified ( $\mathrm{Su}$ and $\mathrm{Lu}, 2015$ ) and the importance of supply chain data in assessing possible defaults has been investigated (Zhao et al., 2015; Bendig et al., 2017), innovative credit assessment models combining financial and supply chain data are still absent, and no literature is available on this theme.

To fill these gaps, the overall goal of the paper is to investigate the possibility to evaluate the credit risk of a company including not only financial indicators, but also operational variables, thus proposing a supply chain credit rating. We define a supply chain credit rating as a model that accounts for information on both the financial performance of a company (in particular a supplier) and its supply chain relationships and operational performance, as perceived by its buyers (and included in their vendor rating systems), to increase the timeliness and responsiveness in predicting future performance, and therefore credit risk. The unit of analysis is therefore still a single company, but the supply chain perspective allows a more complete and reliable assessment.

This fundamental goal is summarized in the following research question: 
RQ1: How can a financial credit rating and a vendor rating be integrated into a supply chain credit rating? What types of information would be useful to combine?

In the development and use of the supply chain credit rating model, each stakeholder has a clear role. Consistent with the indication of the stakeholder theory, the benefits as well as the challenges for each stakeholder should be considered as well. Thereby, the second goal of the paper is the identification of the main benefits as well as challenges of such model for the supply chain (i.e., buyer and supplier), the technology providers and the financial institutions. This goal is summarized in the following research questions:

RQ2: What are the benefits of a supply chain credit rating approach for all the stakeholders involved?

RQ3: What are the challenges of a supply chain credit rating approach for all the stakeholders involved?

The potential value of the supply chain credit rating model is twofold. On the one hand, we argue that the inclusion of variables related to the supply chain could enhance the predictive power of credit risk assessment, thereby reinforcing the accuracy of credit ratings. Second, this model aims at providing value to all the actors involved: buyers, suppliers, financial institutions, and technology providers. In fact, we consider all the relevant stakeholders involved, Consistent with the indications of the stakeholder theory.

\section{Research framework}

Based on the literature review illustrated thus far, we developed a preliminary research framework by combining different bodies of literature on financial credit rating, vendor rating, and stakeholder theory. This choice was made to examine possible relationships between variables, thus increasing internal validity.

To answer the first research question, we adopted the approach oriented to information management (Khan et al., 2016) with a network perspective (Harland et al., 2003) and considered two main groups of variables potentially useful to calculate a rating (as reported in Annex A): variables currently adopted mainly by financial institutions and those currently adopted by buyers in their vendor rating systems:

- Financial rating (Basel, 2004). This variable group pertains to the fair judgment related to the financial situation of a company, developed by either a rating agency or a bank, with the purpose of quantifying the risk to lend money to the company. It entails the financial quantitative factors (Tracy and Carey, 2000) of a company, such as capital structure, profitability, and liquidity, as well as some qualitative factors, such as business and industry models (Grunert et al., 2005).

- Vendor rating (Lasch and Janker, 2013). This variable group pertains to the evaluation of suppliers carried out by a buyer, after receiving the requested goods or services, with the purpose of monitoring the performance. It entails operational parameters, such as quality, delivery, and cycle time (Sharland et al., 2003). For the analysis of vendor ratings, we considered the performance identified by Caniato et al. (2014) to address supplier performance as a combination of efficiency and effectiveness, namely cost, time, quality, flexibility, innovation, and sustainability. Each company might select a different sub-set of these criteria, but for sake of completeness, we decided to include all the different variables. This choice mainly depends on the idea that each company might decide to excel in merely some of these criteria (i.e., order winners, Hill 1999), 
but it needs to meet minimum requirements on the others as well (i.e., market qualifiers, Hill, 1999).

On the other hand, to answer the second and third research questions, we aimed at identifying the main benefits and challenges of a supply chain credit rating. We followed the suggestions of the stakeholder theory (Freeman et al., 2010), which claims that managers should make decisions taking into consideration all the relevant stakeholders (Freeman et al., 2010). Moreover, the literature suggests that stakeholders should be identified based on the specific area of investigation (Harland et al., 2003). Due to our desire to consider the supply chain perspective, we selected as area of investigation the implementation of SCF solutions, considering the main actors involved in the adoption of these tools (Chen and $\mathrm{Hu}, 2011$; Lamoureux and Evans, 2011). First, we considered the buyer (as the actor providing data and evaluation) and its supplier (as the object of the evaluation) (Lambert et al., 1998). Second, we considered supportive actors according to the definition of Pfohl and Gomm (2009): financial institutions (as actors assigning financial ratings to assess the ability to repay debts, such as banks, rating agencies and factors) and technology providers (as enabling actors to share data) (Hoffman, 2005). The preliminary research framework is depicted in Figure 1.

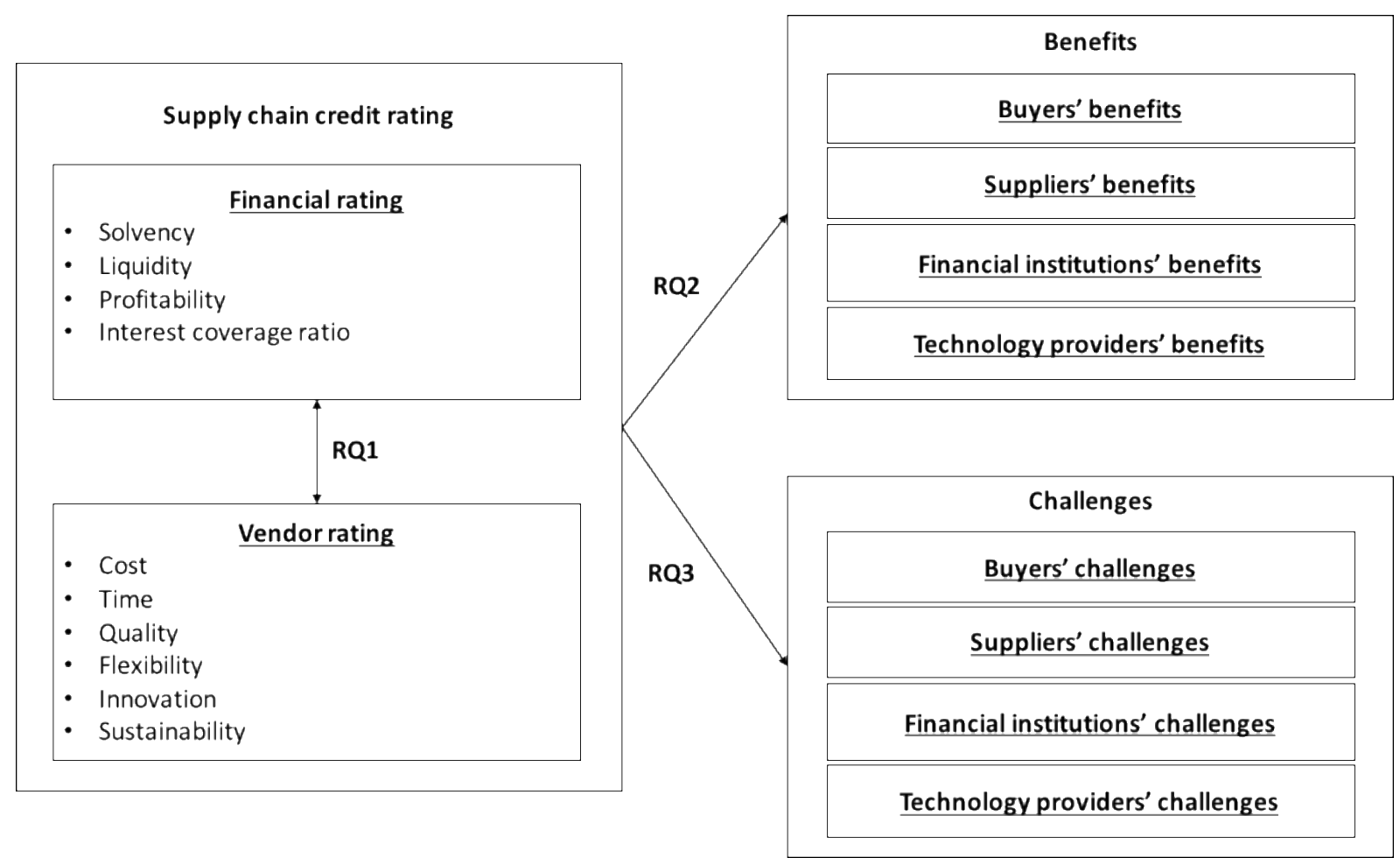

Figure 1: Preliminary research framework

\section{Research methodology}

To answer our research questions, a twofold methodology was selected, involving both case studies and focus groups, as noted previously. We opted for an overall qualitative methodology, as it allowed us to investigate research questions about innovative ways of performing credit rating, not only adopted by researchers (Rubin and Rubin, 2012), but also by industrial companies (both buyers and suppliers), financial institutions, and technology providers, to the best of our knowledge. The case studies aimed at developing the final conceptual framework, thus identifying the main variables to consider. This phase was conducted with an inductive approach and a theory building purpose. Moreover, we performed five focus groups with experts, each one with a different purpose: 
1. to develop questions to ask during the case studies,

2. to discuss the proposed framework developed on the basis of the first round of interviews considering variables to include in the supply chain credit rating,

3. to identify new questions to ask in case study interviews about the benefits of supply chain credit rating

4. to identify new questions to ask in case study interviews about the challenges of supply chain credit rating,

5. and to address the validity and reliability of the framework identified through the case studies.

The two methods were selected following Gioia et al. (2013, p. 5), addressing the importance to "get in there and get your hands in dirty research-madly making notes on what the informants are telling us, conscientiously trying to use their terms, not ours, to help us understand their lived experience." In fact, focus groups were also used to increase the construct validity to review data and results with some key informants of different groups of stakeholders. The two methods are used to cycle among literature variables, emergent data, themes identified in practices, and constructs proposed by the theory.

To ensure the reliability of data collected with both methods, we followed a well-specified research protocol (see Annex B and Annex C); a Dropbox folder was shared among the authors to collaborate and review questions, transcription, and data analysis to increase the reliability of the results. Moreover, one member of the team performed the role of the outsider throughout the study to critique interpretations formulated about the collected data (Van Maanen, 1979).

\section{Case studies}

As mentioned above, we selected a case-based methodology, with an inductive approach (Gioia et al., 2013). Indeed, we aim at contributing to the literature and showing new areas of application of the theory from case study evidence. For this purpose, we selected case studies to be representative of the problem under investigation. In particular, consistent with the indications of the stakeholder theory, we aimed at developing case studies of the main stakeholders involved in developing a supply chain credit rating (buyers, financial institutions, and technology providers). Suppliers were not interviewed because they were the object of the evaluation, so they could be perceived as biased in selecting the main variables to evaluate themselves.

There is debate in the literature about the right number of case studies to consider. In this research, according to the indications of Eisenhard (1989), we selected 10 case studies, which is considered a good number to have comparability of the results along with an in-depth analysis of the cases. We decided to interview four buyers, three technology providers, and three financial institutions. Multiple case studies were used to ensure the validity of the results to compare both different stakeholder perspectives and different views among stakeholders as part of the same group. This sample was defined also to allow the generalizability of the results, thus extending their validity beyond the setting in which they are studied. Companies were selected based on secondary sources of information and on the analysis of their public data, as summarized below:

- Buyers: the four buyers are large international companies, operating in Italy, with an international supply chain and a huge number of active suppliers. These companies belong to different industries as well as have different countries of origin. They were considered because they are the owners of structured vendor rating data. Only large 
companies were considered, as they have had a structured and digitalized vendor rating model in place for several years.

- Technology providers: the three selected companies are Italian players with a central focus on purchasing tools and vendor rating solutions. Technology providers were included because they manage both financial and vendor rating data for the buyers and financial institutions. They were selected because they are explicitly interested in enlarging their offer by including financial rating analysis within their platforms. Companies strongly differ in terms of company dimensions but are thereby representative of different types of technology providers operating in Italy.

- Financial institutions: Three rating agencies were selected because they are the players in charge of providing a financial rating; in particular, they are Italy-based rating agencies, providing not only a traditional rating with a pure financial purpose, but also a financial rating to support a supply chain assessment in terms of the financial solidity of both buyers and suppliers. The financial institutions strongly differ in terms of size but are thereby representative of different types of financial institutions operating at the Italian level and offering services to companies: in this view, we wanted to compare the behaviors adopted by the three main local rating agencies.

The case study sample is illustrated in Table .

\begin{tabular}{|l|l|l|l|l|}
\hline Group & Company name & Industry & Turnover (M€) & \# of employees \\
\hline \multirow{4}{*}{ Buyers } & C1 & Shipbuilding & 3.000 & 20.389 \\
\cline { 2 - 5 } & C2 & Utilities & 962 & 2.694 \\
\cline { 2 - 5 } & C3 & Energy & 12.325 & 3.000 \\
\cline { 2 - 5 } & C4 & FMCG & 809 & 2.637 \\
\hline \multirow{2}{*}{$\begin{array}{l}\text { Technology } \\
\text { providers }\end{array}$} & T1 & ICT provider & 6 & 114 \\
\cline { 2 - 5 } & T2 & ICT provider & 80 & 633 \\
\cline { 2 - 5 } $\begin{array}{l}\text { Financial } \\
\text { institutions }\end{array}$ & F1 & ICT provider & 26.818 & 377.757 \\
\cline { 2 - 5 } & F2 & Rating agency & 175 & 732 \\
\cline { 2 - 5 } & F3 & Rating agency & 378 & 1.942 \\
\hline
\end{tabular}

Table 1: Case study sample

Data were collected through direct interviews and phone interviews, performed in 2016 and 2017. Interviews were conducted through a semi-structured interview protocol (reported in Annex B). The interview protocol has some common questions for all the cases (i.e., buyers, technology providers, financial institutions), as well as specific questions. The main common questions were related to the general description of the company, perception about the current relevance of traditional financial ratings, and identification of the main benefits of a supply chain credit rating. Then, each group of cases had four specific questions. Buyers were requested to explain their current model for supplier assessment and evaluation and to identify the most relevant variables according to their perspective; technology providers were requested to provide examples about integrated approaches adopted by buyers and to identify the most relevant variables according to their perspective; finally, financial institutions were requested to describe their current rating process as well as indicators, to illustrate innovative approaches they are implementing, and to address the main requests they would receive by their customers. The interview protocol for each informant was revised during the interviews based on both insights collected through the focus groups and insights collected by previous interviews. If additional questions were added or some questions were deeply revised, previous informants 
were contacted again by phone or by e-mail to collect missing data. The version of the interview protocol reported in Annex B is the final one.

In each case, more than one informant was interviewed; people involved were purchasing managers and finance managers for buyers, marketing people and analysts for financial institutions, technical people and sales people for technology providers. In each case, all the roles involved in the process were interviewed. Interviews were always recorded, with permission of the interviewed person, to avoid information loss. Each interview lasted from 60 to 120 minutes and was conducted by at least four researchers. Beyond direct interviews, data validity was verified through the triangulation of data with the support of secondary data, such as companies' presentations, company financial reports, financial rating methodologies and parameters reported into the websites, direct observations during the interviews, and financial data collected through AIDA (the database of financial reports of Italian companies).

Data analysis was performed in four different steps, i.e., within-case analysis, cross-case analysis among cases of the same groups, cross-case analysis among groups, and a theorybuilding phase. Within-case analysis was performed based on recorded data to aggregate information of different interviews in common paragraphs. Within-case analysis aimed also at identifying the first-order categories, considering all the different views of different informants involved. In the case that some data were missing or not clear, the company was contacted again by phone to clarify the information. To maintain the narrative of findings, in our within-case analysis we also collected several quotations from the main informants. Cross-case analysis was performed by comparing data with first-order tables among cases of the same group and with a second-order table among cases of different groups. Cross-case analysis was performed to check whether the emerging concepts can help us in understanding the phenomenon under investigation. Finally, in the theory-building stage, we iterated between data, literature, and stakeholder theory and developed the framework. In the data analysis process, two researchers were involved to triangulate information and increase descriptive validity.

\section{Focus groups}

To guide and direct our case studies and to discuss the proposed framework, we involved several experts in dedicated focus group meetings. We selected this methodology, as previous research identifies it as able to provide in-depth information through interactive discussion (Pettit et al., 2010; Goldman, 1962) and investigating complex topics (Pettit et al., 2010). The goal was not to promote consensus on the proposed framework but to gather a broad base of information on such a complex issue (Pettit et al., 2013; Morgan, 1996). We therefore facilitated five focus groups in 2016 and 2017 for approximately three hours each with an average of 23 senior-level participants, in charge of the activities under investigation. Following the stakeholder theory (Freeman et al., 2010), we considered different views by involving representatives of all the stakeholders, who asked to remain disguised. In particular, we involved representatives from 10 financial institutions, 10 buyers including three associations, and 5 technology providers (see Table 2). The goal of the focus group was to collect the voice of the key informants and to treat them as knowledgeable agents.

\begin{tabular}{|l|l|l|l|}
\hline Group & Company & \multicolumn{1}{|c|}{ Industry } & \multicolumn{1}{c|}{ Job title } \\
\hline \multirow{4}{*}{ Buyers } & C5 & Electronics & Customer Finance Manager \\
\cline { 2 - 4 } & C6 & Healthcare & $\begin{array}{l}\text { Head of Southeast Europe Scientific \& Clinical } \\
\text { Procurement }\end{array}$ \\
\cline { 2 - 4 } & C7 & Heating systems & Group Procurement Director \\
\cline { 2 - 4 } & C8 & Fashion Association & Business Development Manager \\
\cline { 2 - 4 } & C9 & Industrial Association & Credit and Finance Area \\
\cline { 2 - 3 } & C10 & Professional Association & Board Member \\
\hline
\end{tabular}




\begin{tabular}{|l|l|l|l|}
\hline \multirow{4}{*}{} & C11 & $\begin{array}{l}\text { Electrical low voltage } \\
\text { equipment }\end{array}$ & CPO \\
\cline { 2 - 4 } & C12 & Power generation & Manager \\
\cline { 2 - 4 } & C13 & Heat exchangers and coolers & Investments Manager \\
\cline { 2 - 4 } & C14 & Canned fish & CFO \\
\hline \multirow{5}{*}{$\begin{array}{l}\text { Financial } \\
\text { intitutions }\end{array}$} & F4 & Investment fund & Alternative Investment Fund - Financial Analyst \\
\cline { 2 - 4 } & F5 & Factor & Head of Financial Services \\
\cline { 2 - 4 } & F6 & Bank & Head of Financial Services \\
\cline { 2 - 4 } & F7 & Bank & Head of Marketing Operations - Corporate Division \\
\cline { 2 - 4 } & F8 & Bank & Head of Innovation Lab \\
\cline { 2 - 4 } & F9 & Credit card provider & Head of Sales B2B \\
\cline { 2 - 4 } & F10 & Rating agency & Head of Fin. Institutions Products \& Data Sources \\
\cline { 2 - 4 } & F11 & Rating agency & Marketing, Product \& Business Development Large \\
& & & Corporate \\
\hline \multirow{5}{*}{$\begin{array}{l}\text { Technology } \\
\text { providers }\end{array}$} & T4 & Technology consulting & CEO \\
\cline { 2 - 4 } & T5 & Information provider & Risk Account Director \\
\cline { 2 - 4 } & T6 & Technology consulting & Analyst \\
\cline { 2 - 4 } & T7 & IT provider & CTO \\
\cline { 2 - 4 } & T8 & IT provider & Business Line Executive \\
\cline { 2 - 4 } & & & Solution and Delivery Manager \\
\hline
\end{tabular}

Table 2: Focus group sample description.

Participation was voluntary, but delegates were almost always present in all meetings, as we sent invitations for the first meeting one month in advance, while we jointly agreed on the following ones.

We provided each participant with information about the scope of the discussion in advance. During the meetings, we took notes; once completed, we merged notes and summarized the discussion, also preparing some take-away slides that we sent to participants a few days after.

We jointly ran the meetings acting as moderators and initiating them with a brief on the topic and on previous discussions without biasing participants' opinions. Iterations during meetings allowed a better understanding of the subject and critical effective discussion, with a better definition of the framework, the benefits, and the challenges.

During the first meeting, we discussed the data that should be shared among different parties to allow the formulation of a supply chain credit rating. To do this effectively, we prepared a very short case that we gave to participants at the beginning of the meeting in two different versions (see Annex C). We asked experts to look at the case from the perspective of their counterpart. In other words, we asked representatives of financial institutions, technology providers, and rating agencies to act as if they were industrial company managers and the other way around for industrial companies. We then discussed, for the identified data, both their relevance and the cost of gathering such information. We then asked participants to provide examples of the cases. The results of the first focus group were used to shape the interview protocol to use in the case studies.

During the second meeting, we gathered information about data to consider in the supply chain credit rating, also considering the preliminary results of the case studies.

In the third and fourth focus groups, we concentrated on the benefits of such information sharing and related challenges. While we had these meetings during the development of the case study, the last meeting was devoted to assessing the validity and the reliability of our framework and discussing it. Details about the questions asked in each meeting are reported in Annex C. 
The existing link between focus groups and case study interviews is illustrated in Figure 3.

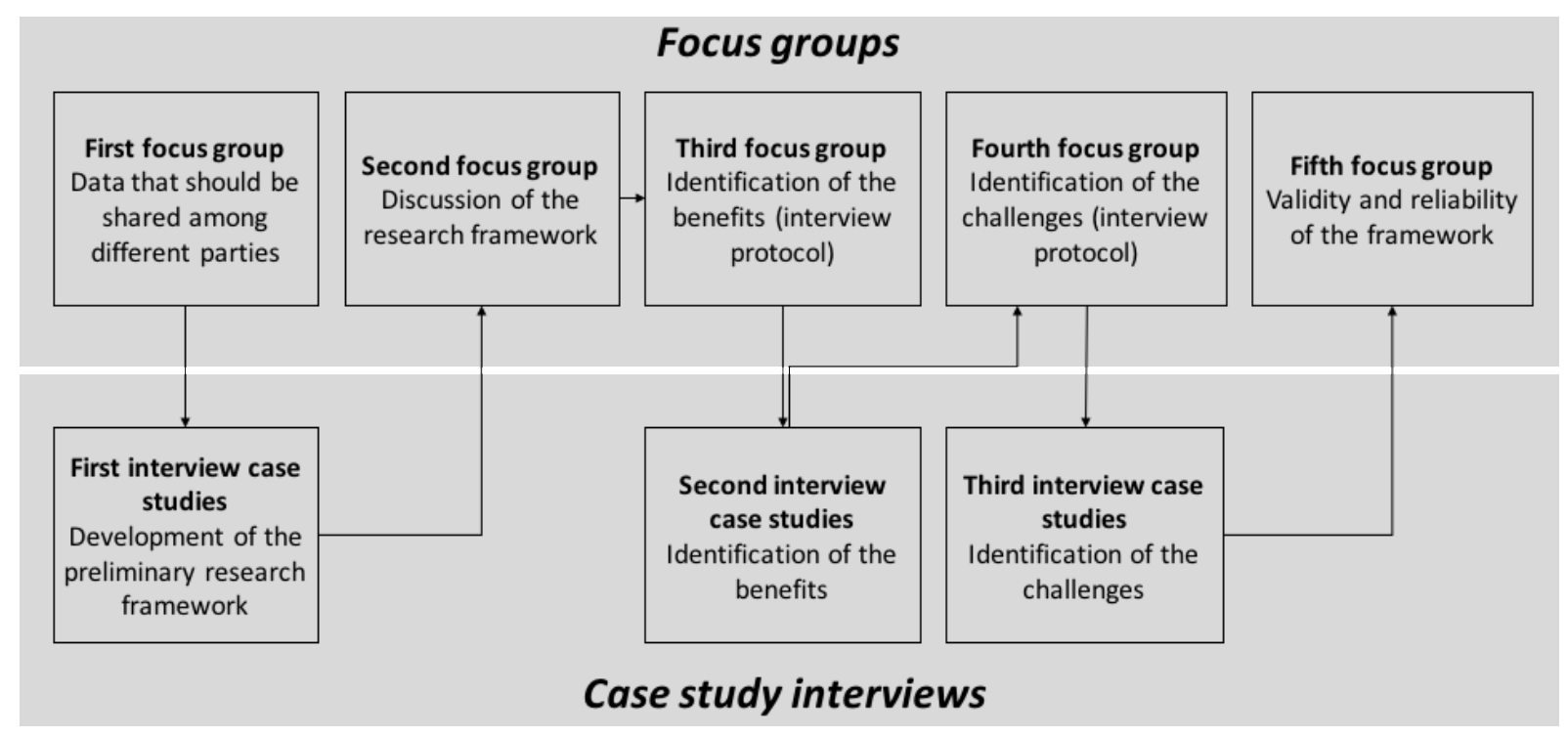

Figure 3: Links between focus groups and case study interviews

\section{Supply chain credit rating development}

\section{Overview of the issue}

During the first two focus group meetings, several considerations arose about the possibility to consider additional views, besides the financial one, in credit risk estimation.

The discussion was introduced by describing some examples, oriented to demonstrate the importance of broadening the focus beyond pure financial data: several examples were reported by senior managers about their personal professional experience.

The first example was the situation of a small software house with a poor financial rating, mainly due to the long payment terms imposed by a few large buyers; in spite of this poor financial rating, buyers were very satisfied with the products and services of the software house, resulting in very good vendor rating metrics considering all the surveyed parameters. Buyers were willing to continue working with this supplier, who had become a strategic partner for them. This example is hinting that better financial support would allow the company to grow and become stronger, also from a financial perspective, while providing a good business opportunity for financial institutions.

The second example suggests, however, misalignment between financial rating and vendor rating is not an issue merely for small companies. We were told about the case of a large construction supplier operating in the infrastructure sector, which had a very good financial rating in 2011, but which started decreasing in the following years, and finally experiencing default in 2013. The bankruptcy of the supplier was quite unexpected by the financial institutions, which were expecting a recovery due to the positive path in terms of previous ratings. But analyzing the vendor rating performed by the buyer, it would have been clear since 2009 that this supplier was in great trouble. The vendor rating showed a clearly visible decline in all parameters (i.e., on-time delivery, quality, responsiveness, flexibility, compliance, price). The availability and use of such information could have given support to the financial institution in assessing the real situation of the supplier much sooner. This example also highlights two 
key considerations: first, it is not simply a matter of the current operational performance (measured in the vendor rating system), but rather the performance trend is much more relevant; second, the vendor rating appears to be more reactive than financial rating in detecting a change in the supplier situation, thus being able to predict future problems earlier.

Participants in the focus group also reported examples of the alignment of the two ratings, i.e., financial and vendor ratings, both for small and large companies. We found example of alignment in the case of a consulting firm (supplier) with revenues of about 10 million $€$, with both a financial and a vendor rating considered high and stable over time. Another example of alignment is the case of a large supplier operating in the software development business with poor scores on both financial and vendor ratings, which were deteriorating over the years.

Such examples give additional support to our hypothesized framework regarding the possible improvement in credit rating evaluation, thanks to the combination of financial and vendor ratings. When both perspectives are aligned, the credit rating can be considered more reliable; when they provide contrasting messages, further investigation is needed.

Based on this preliminary evidence, focus group participants identified a potential subset of data to be shared between buyers and financial institutions to improve credit rating, to be investigated through the case studies. We can summarize the variables identified during the discussion in terms of the following:

- Vendor rating data: data about the supply chain, considering the various suppliers involved. These data include performance indexes, e.g., on-time delivery, compliance, stock level, sustainability, and innovation.

- Descriptive data: information about the intrinsic features of the relation between buyer and supplier, such as the strategic importance of the relationship, the duration of the relationship, the interchangeability of the supplier, the supplier's dependence on core buyers, second-tier suppliers, and the impact of the supplied goods on the buyer's final product.

- Financial data: details on financial flows, such as the frequency and amount of transactions and payment terms, and financial instruments including the usage of SCF mechanisms, such as reverse factoring.

After this classification, financial institutions wanted to deepen into vendor rating data and descriptive data, to better understand the potential value of such data. Data were then classified in a matrix (as depicted in Figure 4) to categorize these pieces of information according to two dimensions: the relevance of the data in terms of value added to the traditional financial information and the cost of data gathering, to collect the data and integrate them with the financial ratings. This classification was useful to define future priorities, with clear attention to those data in the high-relevance blocks. In particular, in terms of vendor rating data, focus group participants agreed that price is more a matter of positioning and not a parameter with an evolution over time, and thus not as relevant for credit ratings; in the same vein, sustainability and innovation are definitively important, but more long-term oriented as well as already somehow considered into financial ratings. On the other hand, the analysis of the impact of the supplied item on the buyer's product is quite technical and difficult to integrate into an evaluation as well as the data related to second-tier suppliers. However, it helped us in highlighting the relevance of some "descriptive data," in spite of their cost of being gathered; therefore, we included them in our revised framework.

\begin{tabular}{|l|l|l|l|}
\hline Relevance & High & ${ }^{\circ}$ Interchangeability of suppliers & $\begin{array}{l}{ }^{\circ} \text { Dependence on core buyers } \\
{ }^{\circ} \text { Relationship duration }\end{array}$ \\
\hline
\end{tabular}




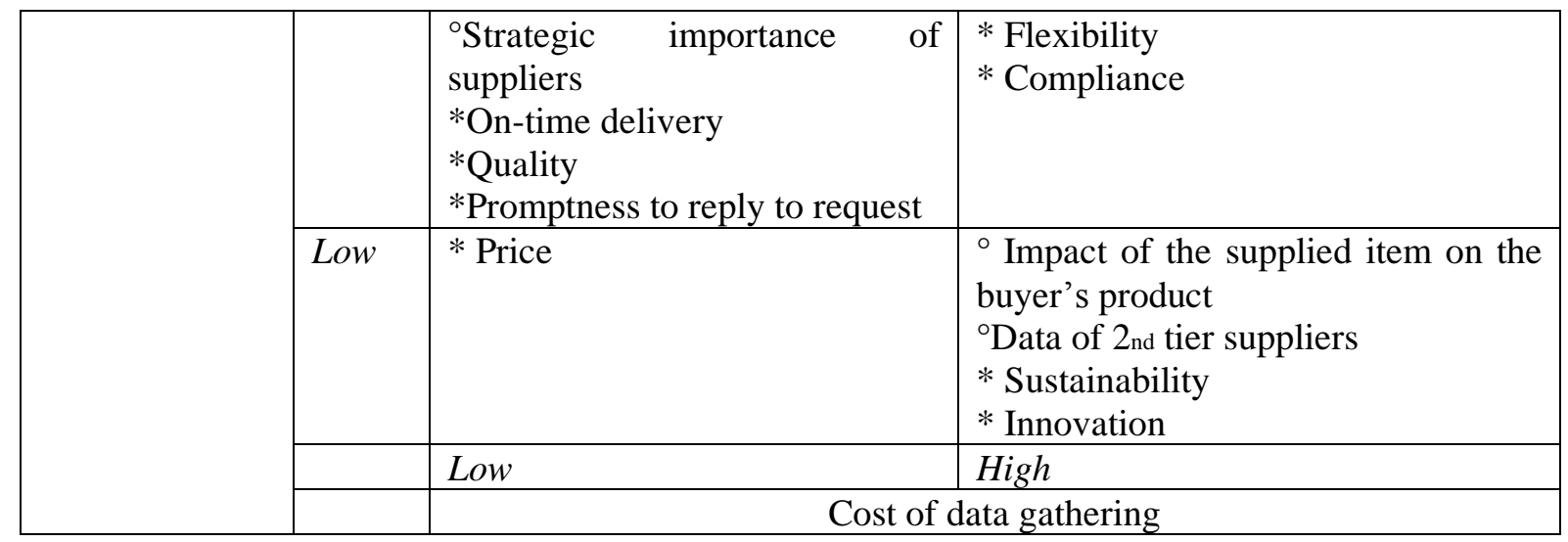

Figure 1: Relevance and cost of gathering of data to be shared by buyers with financial institutions. *vendor rating data ${ }^{\circ}$ descriptive data

Integration between financial and vendor rating data

Case studies were used to identify financial and vendor rating data considered by buyers and technology providers as well as to understand whether they are already somehow integrating the two views: in Annex D, the cross-case analysis is reported. In this analysis, buyers highlighted the need for a holistic overview-integrating financial and vendor rating performance - to have a better understanding of their supply base. As support of this evidence, the buyers are already trying to merge financial and vendor rating data (e.g., C1, C2, and C4) to achieve a final joint rating to evaluate each supplier. These buyers are already developing these models internally, often without any involvement of either financial institutions or technology providers. Having identified a business opportunity in this direction, some technology providers (e.g., T1) are evaluating the feasibility of introducing new services that would allow the integration of vendor and financial ratings inside the same platform.

Among all the cases investigated, it is particularly interesting to illustrate more in depth the model implemented by $\mathrm{C} 1$. C1 is a company operating in the Engineering-to-Order industry, with an average duration of a contract around two years. They clearly said: "The supplier failure is a major risk for us, with potential huge impact for our supply chain in economic terms. If a supplier is going out of business, we could have a cost increase up to 2 million $€$ for searching a new supplier, managing the negotiation, losing some margins, paying penalties for the delay, etc. Thereby, we started developing a joint model that aims at integrating the operational evaluation with the financial evaluation to quickly detect the critical cases. In the case a problem appears, we can go more in depth in the analysis and start implementing some mitigation strategy in advance (e.g., looking for a substitute supplier, developing an ad hoc insurance, set up a supply chain finance contract with the supplier, etc.)." This case is a very good example of how buyers are perceiving a benefit from the integration of financial and vendor ratings and thereby are willing to implement these models within their companies. This is also confirmed by T3, who mentioned: "A financial assessment gives an ex-post signal, while operational data deliver an ex-ante information about suppliers."

These results reported the higher capability of vendor rating data to predict the future performance of companies in a timely manner: in fact, financial data are incorporating the insights of vendor ratings data (i.e., operational performance) but with a certain delay. The integration of the two views would allow both structured information (through financial rating) and higher predictability of future performance. 
In our case studies, we also investigated the operational performance with the highest potential value in terms of integration with the financial institutions. Responsiveness is perceived as particularly important, as it is a good proxy for possible problems for the supplier. For example, company $\mathrm{C} 2$ said: "If a supplier was always able to respond very quickly to our requests and then totally unexpectedly is not satisfying our requirements anymore, it is very likely that a problem has occurred. Perhaps they acquired a new big customer, but often it is a problem in terms of cash. The issue is that financial data are giving us this information only several months later." On the other hand, most companies (e.g., C1, C2, T1, T2) suggested that price is not as relevant for this purpose. Similar considerations are identified for innovation and sustainability performance: in fact, some companies (e.g., C1, C3) highlighted that these parameters are highly important for the selection of a supplier, but not as useful to include into a supply chain credit rating because of their lack of timeliness in preventing possible problems. This result is consistent with the results of the focus group reported in Figure 4. Thus, thanks to the combination of focus groups and case studies, we selected the most relevant vendor rating metrics.

An additional key point that emerged from the case study is the importance of the performance trend: in fact, vendor rating data are mostly relevant considering their trend, rather than the absolute value. In fact, to predict possible changes in the performance of a company, it is much more important to look at the evolution of vendor rating data rather than their single values. This consideration was also reported for two other reasons. First, by looking at trends, the different scales adopted by buyers are less impacting because only tendency values are compared; second, suppliers are not likely to be excellent in all performance dimensions, since each one has a different strategy; therefore, looking at the performance evolution over time is more reliable to assess the credit risk of the supplier.

Moreover, we also performed case studies of financial institutions to go more in depth in understanding the way they perform credit rating. In particular, financial institutions allowed us to understand the relevance of the topic under their perspective and to identify potential new variables to incorporate into their financial rating. Annex D summarizes the main results. The financial institutions confirmed the importance of jointly considering the financial and vendor rating perspective to assess the credit risk. To confirm this importance, some of the financial institutions are already evaluating new parameters to consider the supply chain perspective through an emphasis on payments (e.g., F2 considers delays in payment along the supply chain) or with a main supply chain focus (e.g., F3 collects supply chain risk data). But the financial institutions also confirmed that the current level of integration is still not sufficient, especially for assessing small suppliers. We report the opinion of F3 in this respect: "A supply chain perspective is fundamental to have a correct view of each supplier, especially if very small. But financial analysis is not currently integrating this perspective, beside the fact that financial data are not very reliable for small companies."

Based on these considerations, we were able to formulate our first research proposition:

RP1: A supply chain credit rating - i.e., the combination of financial rating and vendor rating assigned by buyers - improves the accuracy of credit risk assessment of a supplier.

In line with the comments raised by the first focus group, a second issue was discussed. The case studies suggested that the first internal attempts of supply chain credit rating are mainly performed by buyers for strategic suppliers only. There are two main reasons for this choice: the desire to minimize the effort necessary to develop a supply chain credit rating and the higher reliability of the data. For example, case $\mathrm{C} 2$ said: "We are used to evaluating the performance 
in depth with an integrated approach just for direct and strategic suppliers." This result is also confirmed by F1, who highlights the importance of considering the strategic perspective in the evaluation of vendor rating data integrated with financial data: "Vendor rating data are a very useful potential source of information, but not all the suppliers are equally important for a buyer. If the performance is provided by a buyer that has a long-term, strategic relationship with the supplier, and therefore is able to monitor the evolution of the performance, I believe this additional information is strongly valuable. On the contrary, if it is just a one-shot supplier, the data might be also interesting, but I do not believe they are so reliable."

These results demonstrate and support the possibility of adding a new variable into the framework related to the level of the strategic relationship between the buyer and supplier, as already suggested by the first two focus groups. However, we noted that these data did not affect the interactions between financial and vendor ratings, but more precisely they reinforced the relevance of such integration, acting as a moderator.

Based on this additional consideration, the second research proposition was formulated:

RP2: The strategic relevance of the supplier for the buyer positively moderates the benefits of the integration of vendor rating data with financial data, thus increasing the predictive power of a supply chain credit rating.

\section{Supply chain credit rating benefits}

\section{Identification of the benefits}

The second purpose of our case studies was the identification of possible benefits for all the stakeholders involved (Annex F). Each company was required to illustrate the benefits they would expect for their role and for the other stakeholders impacted. This choice was based on the stakeholder theory approach that we adopted in the study.

Consistent with the indications of the stakeholder theory, case studies have clearly shown that the implementation of a supply chain credit rating could have important benefits for all the actors involved. In fact, the identified benefits appear to be of a different nature (i.e., financial, operational, relational, etc.), in line with the role that each actor plays in the relationship. The identification of the nature of different benefits is relevant to overcome potential trade-offs that might occur between different goals, challenging the implementation of the model, as suggested by the stakeholder theory.

Considering suppliers' perspective, most of the companies mainly addressed the financial benefits. A good supplier might have easier credit access, usually at a lower cost as well. As T3 said, "I think for start-ups the operational evaluation should be more relevant than the financial one to obtain money"; or as C3 said, "In a SCF project I developed some months ago, the financial institution asked some operational information to gain in-depth knowledge about the supplier to lend them money." $\mathrm{C} 1$ reported the possibility to support suppliers in obtaining financing at a reasonable cost through the supply chain credit rating, thereby reducing their overall probability of default. Finally, some players mentioned that the adoption of this approach would put the supplier in a preferred position in relation to the buyer, with a consequent further improvement of the supplier relationship with the buyer. As a matter of fact, it is important to consider that the supplier might achieve benefits just in case that additional information is improving its personal rating; otherwise, additional data might also show that the real situation of the supplier is worse than the one depicted by financial data only, thus reducing the possibility for the supplier to gain access to credit. The supplier is the only 
stakeholder with this twofold view of the integration, as it could see both an improvement or a deterioration of its rating (although in both cases it would be more accurate).

Based on these considerations, we formulated the following research proposition:

RP3a: A positive supply chain credit rating would provide benefits to suppliers mainly with a financial perspective, in terms of increased access to funding, reduction of credit cost, reduction of default probability, and improvement of the relationship with the buyer.

Considering the perspective of the buyer, the main benefits identified are mainly related to the management of the supply base. The most relevant achievement is related to better knowledge of the suppliers, allowing the adoption of adequate mitigating strategies to reduce supplier risk. For example, T3 mentioned, "This supply chain credit rating leads to a better evaluation of the risk of a supplier and its evolution." As mentioned for the supplier perspective as well, through this approach and given that companies are likely to use this rating with strategic suppliers, the relationship is reinforced with a long-term perspective. This result is relevant to identify the reasons for buyers to share these data with other stakeholders: one reason is that supporting the access to funding of the supply base reduces their costs and risks, thus resulting in lower costs for the buyer; in addition, in exchange for sharing vendor rating data with the financial institution, the buyer could access better information about the risk of its suppliers, thus being able to reduce such risk through adequate mitigation plans.

Based on these considerations, we formulated the following research proposition:

RP3b: A buyer relying on a shared supply chain credit rating for its suppliers would achieve benefits in terms of improvement of supplier relationship, lower purchasing costs, improvement of supplier risk assessment, and more in-depth supplier knowledge.

Through our case studies we identified potential benefits for financial institutions as well. In fact, a supply chain credit rating might support financial institutions with both a risk and a commercial benefit. On the one hand, they could better assess the risk of suppliers, particularly smaller ones, thereby better allocating their funds, as underlined by most of the interviewees. On the other hand, thanks to more in-depth knowledge about suppliers, they could improve their offering of financial services to companies, thus being able to direct the commercial effort in a more effective way.

Based on these considerations, we formulated the following research proposition:

RP3c: A supply chain credit rating would provide commercial and risk mitigation benefits to financial institutions in terms of better assessment of default probability and better allocation of funds.

Finally, technology provider cases clearly declared a potential market value, with a clear commercial and service development purpose. As mentioned by T3, a tool supporting the integration and sharing of financial and vendor rating data might provide a twofold opportunity: including an additional service into their offering, thus extending the customer base to include both industrial companies and financial institutions, and maintaining long-term relationships with buyers, given that the integration might require the collaboration with multiple actors.

Based on these considerations, we formulated the following research proposition: 
RP3d: A technology provider offering solutions supporting supply chain credit rating would achieve commercial benefits in terms of new market opportunities.

\section{Validation of the benefits}

Experts in the third focus group strongly debated about the possible benefits of a supply chain credit rating for the various stakeholders involved. In particular, financial institution experts highlighted their ability to better understand suppliers - especially small companies - not just based on financial and accounting data that are often not very reliable for such companies, but also through the information provided by their large buyers. Richer information would enable financial institutions to adopt a consulting approach, thereby helping suppliers with timely financial support, not only when problems arise, but also in advance. The focus group discussed this element in depth because the identification of the potential benefits of a supply chain credit rating highlighted a potential major change in the role played by the financial institutions, moving from being only providers of funds to become strategic consultants of the suppliers. Another element to highlight is the value of time: through a supply chain rating, financial institutions might increase their predictive capabilities, thus being able to anticipate the future needs as well as problems of suppliers. Moreover, financial institutions addressed that a reliable vendor rating might improve the non-financial data - generally considered within the current rating only on the base of questionnaires filled in by the supplier - through structured data provided by a third party (the buyer). This suggests that vendor rating data are not alternative to the process already used by financial institutions, but it is an additional tool to increase the value of the final rating as well as to increase the contribution of the analyst. As a matter of fact, to achieve these benefits it is necessary that real-time data are shared, with a clear visibility on the single components of vendor rating and not in an aggregated way. If just a single indicator, representative of vendor rating, is shared, most of the mentioned value would be lost.

Suppliers would have the opportunity to obtain smoother access to liquidity, not only through SCF solutions but also directly. Indeed, the supply chain credit rating is beneficial for the relationship independently from the adoption of specific SCF solutions. Moreover, given that the analysis of credit rating is more accurate, suppliers might have a potential reduction in the credit cost. All these benefits are not just financial, as the experts remarked that this would be the only chance for small suppliers to avoid or reduce the probability of default. In fact, the focus group reported the importance of clearly showing this potential value to the supplier that otherwise might just be afraid of sharing data with third parties.

The focus group reported that buyers could obtain some benefits as well. First, a buyer that shares its vendor rating data would receive in exchange more precise financial data about suppliers, thereby improving its suppliers' knowledge and reducing the risk profile linked to the supplier's default probability, especially for strategic suppliers. Moreover, the buyer, supporting suppliers in this financial process, would improve the relationship with the supply base, thereby fostering strategic and long-term relationships based on trust and collaboration. This point is especially relevant for two main reasons: first, buyers are the critical node in the collaboration, as they are the ones to convince to share information and therefore the clear identification of their benefits might be the trigger to start the process. Second, buyers might initially expect some financial benefits, which are not likely to be obtained: the identification of proper realistic benefits for all the actors might support the overcoming of this misunderstanding and help the network in identifying the right levers to rebalance the financial values among all the stakeholders. The importance to show benefits to buyers was deeply discussed because insights collected through the empirical analysis addressed that often buyers simply fail to understand the real benefits in sharing this data. Without a pivotal role played by buyers, the supply chain credit rating is not reliable and so a fundamental point pertains to the 
possibility to clearly demonstrate to buyers the value they can get through this model, for example relying upon some pilot cases.

The focus group also discussed potential benefits for technology providers, confirming their desire to establish a partnership with some buyers and financial institutions to include a new solution into their offering. This service is perceived as particularly valuable, especially for the commercial evaluation of supply chain partners. Again, this advanced tool might become a commercial lever for proactive technology providers able to support buyers and suppliers with a dedicated and value-added service.

According to previous insights, the conceptual framework for what concerns benefits was revised, as depicted in Figure 5.

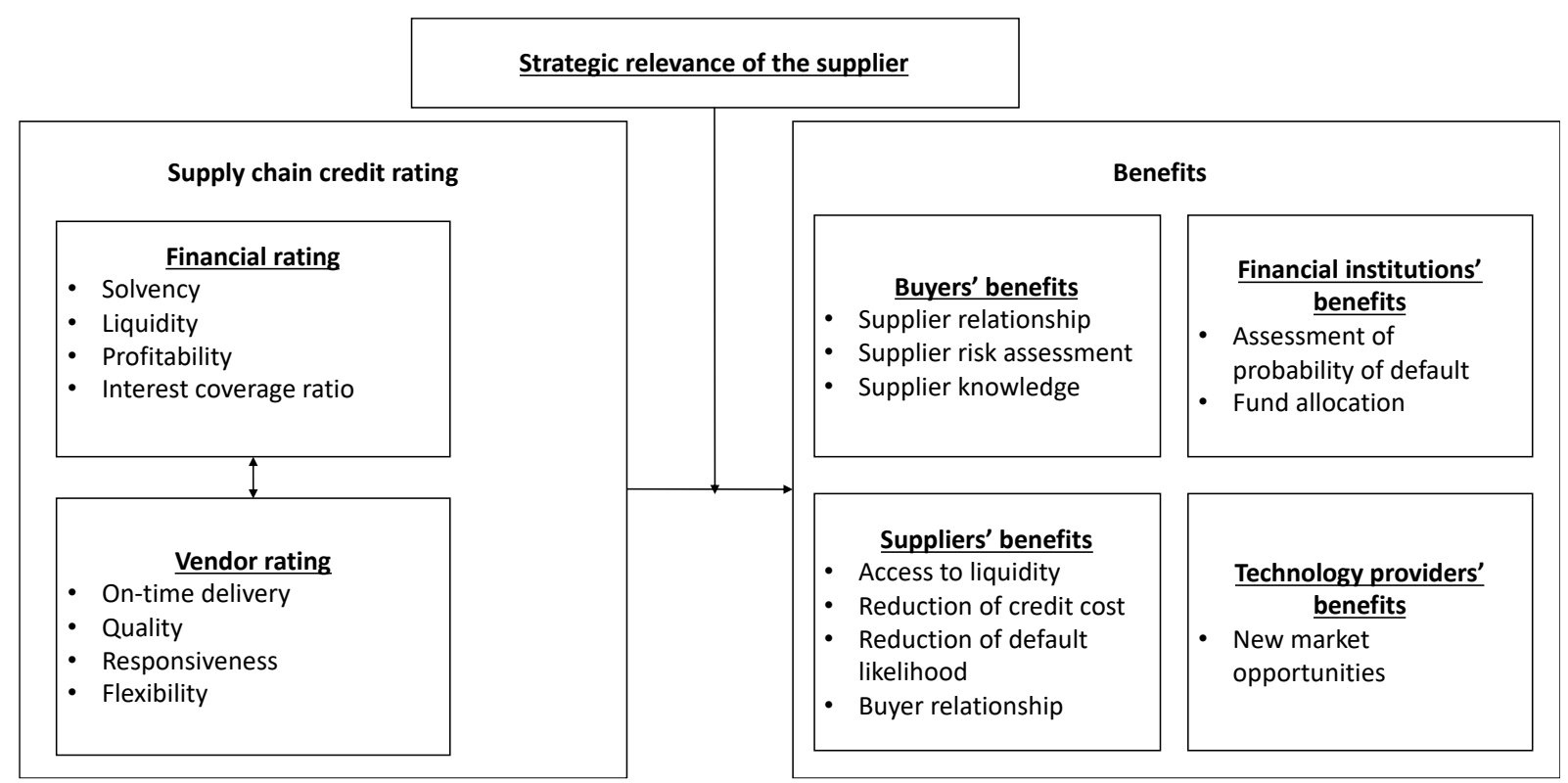

Figure 5: Benefits of the supply chain credit rating

\section{Supply chain credit rating challenges}

\section{Identification of the challenges}

The third purpose of the case studies was to identify the main challenges of a supply chain credit rating. Consistent with the approach followed for the benefits, each company was required to illustrate the challenges they would face in their role, but also for other stakeholders impacted. The choice was driven by the stakeholder theory approach adopted in this study. The main results of the cross-case analysis are reported in Annex G.

Considering the suppliers, several companies mentioned that the major challenge might be related to the risk that the evaluation is negative and so the impact for the supplier is also negative. The example reported by $\mathrm{C} 3$ is very clear: "The situation is thorny for the supplier because if I say that the supplier is not good and the financial institution considers my evaluation, the supplier can face funding difficulties." This is definitively the main challenge that emerged and the main trade-off in the perceptions of the different stakeholders. One potential solution to overcome this challenge is to demonstrate that shared visibility is also a way to jointly look for improvement plans: in fact, given the main focus on a supply chain credit rating for strategic suppliers, the buyer itself is interested in looking for risk mitigation strategies and financial support to overcome the issue. A timely detection of the problem is not 
pursued to abandon the supplier, but instead to have the time to implement an adequate recovery plan. This problem highlighted the need for trust along the supply chain to ensure that the supplier is on the same page with both the buyer and the financial institution.

A second challenge is reported by $\mathrm{C} 2$, who mentioned a potential problem in terms of confidentiality, especially if these data are made public: "It can be risky for the suppliers because if it is going not well, this information would be accessible by buyers but also competitors." This challenge was reported, but is apparently quite weak, as data would not be publicly shared but simply used within the relationships for a better evaluation of each actor.

Based on these considerations, we formulated the following research proposition:

RP4a: A supply chain credit rating would provide challenges to suppliers mainly in terms of the impact of a negative evaluation.

By analyzing the data from the buyer perspective, two main challenges were mentioned. The first challenge is mainly related to the desire to internally integrate financial data with vendor rating data and pertains to the problem of the aggregation of data coming from different departments with different purposes. This was reported by $\mathrm{C} 1$, who faces some challenges in collecting past data created by many different departments (e.g., quality, procurement, R\&D, finance). This is a challenge if the buyer is implementing the model autonomously, while the approach suggested by the stakeholder theory allows this challenge to be overcome. The value of adopting a network approach, with the joint involvement of the buyer, supplier, financial institution and technology providers, is precisely aimed at reducing this problem. In fact, in a joint project the buyer is required to share vendor rating data with technology providers, who are in charge of integrating data from different departments, as well as from different actors (buyer and financial institution).

Indeed, the second challenge is related to the possibility of sharing internal data with external stakeholders, such as financial institutions or technology providers. A quote by $\mathrm{C} 4$ is exemplary in this sense: "We asked the headquarters about the possibility to share data with an information provider, but the answer was no because of confidentiality issues." This is mainly an internal problem, as data are produced by the buyer, so the buyer can decide to share them with third parties; there are no external regulatory constraints in this regard. In this vein, the buyer should clearly understand the value achievable by sharing vendor rating data with third parties to overcome this internal problem.

Based on these considerations, we formulated the following research proposition:

RP4b: A supply chain credit rating would provide challenges to buyers, mainly in terms of confidentiality.

The main challenge for the financial institution is related to the assessment of the validity and reliability of data, to be able to include them in their credit rating. For example, $\mathrm{C} 2$ reported the evaluation subjectivity: "If a financial institution collects information about a supplier by several buyers, the problem is that these data are subjective and, so, how to use such information is a challenge." The discussion in the focus group addressed that this challenge might be actually mitigated in four ways: first, subjectivity is reduced by considering structured data, based on objective performance, such as on-time delivery and quality. Second, by taking into account data just for strategic suppliers, the information is made much more reliable. Third, collecting more data increases validity: if vendor rating data are collected by different strategic buyers for each supplier and, more important, steadily over time, subjectivity is strongly 
reduced. Fourth, as mentioned above, vendor rating data are an additional piece of information added to existing qualitative information, thus allowing for the triangulation of sources.

A second challenge mentioned in the focus group was the lack of standardization of information. As addressed by C3: "The grade 'good' given by a buyer to its supplier is not always equivalent to the 'good' given to the same supplier by another buyer...it is difficult to standardize the information." This is a key point raised in several cases and important to consider. Some financial institutions mentioned the importance of strong collaboration with the buyer to overcome this issue, but in fact the need to establish a strong collaboration might reduce the possibility to scale up the model to a large number of actors. Other financial institutions mentioned the important role of trend data rather than single values to minimize this issue: no matter what the current value of the performance is, the evolution over time should be considered to show improvements or deteriorations.

Some financial institutions addressed the problem of buyers' willingness to share information. For example, R2 mentioned this issue: "Information sharing is another problem and depends on the willingness of the buyers in sharing it." As mentioned above, this is definitively a key point; therefore, it is very relevant to clearly demonstrate to buyers the real value for them of a supply chain credit rating.

Finally, the last critical issue pertains to data aggregation and alignment because the challenge is how to make these new data meaningful within the overall rating. F1 mentioned: "We are considering several new variables, including a few with a supply chain perspective. The problem is to understand the right way to integrate these data within the rating in a meaningful way." Again, as mentioned above for the buyer, part of the problem could be solved through the approach suggested by the stakeholder theory, by involving all the relevant parties: indeed, this might be a great opportunity for technology providers. In fact, to effectively overcome this issue, there is also the need to perform a regulatory check, to ensure that the new model is consistent with Basel requirements. Indeed, financial institutions face uncertainty about the position of the regulator toward such innovative approaches. Under the Basel framework, currently the credit risk for a financial operation (e.g., lending) is assessed considering only the company involved in the operation. While financial institutions can start internally to collect and record supply chain data, obtaining the regulator's approval may take very long, with the risk of wasting time, effort, and IT and organizational costs.

Based on these considerations, we formulated the following research proposition:

RP4c: A supply chain credit rating would provide challenges to financial institutions mainly in terms of evaluation subjectivity, the lack of standardization of information, information sharing, data aggregation and alignment, and regulatory approval.

Finally, by considering the perspective of technology providers, two main challenges were identified. The first pertains to the possibility to catch the business opportunity due to some problems in terms of confidentiality; in the case of technology providers, this issue was mentioned in terms of both receiving data (e.g., C4) and providing data to third parties (e.g., T2). As mentioned above, this problem is internal to the buyer; thus, a cultural change as well as a clear understanding of the value of the supply chain credit rating by all the actors is necessary to overcome it.

The second pertains to the possibility of aggregating data within a single rating, by considering that different buyers and financial institutions might have different needs and preferences. This is definitely a challenge, but it is also mentioned by some technology providers as part of their 
business routine and thus can also be considered an embedded risk of a technology provider's activities.

Based on these considerations, we formulated the following research proposition:

RP4d: A supply chain credit rating would provide challenges to technology providers, mainly in terms of confidentiality and in terms of data aggregation and alignment.

\section{Validation of the challenges}

Experts in the focus group strongly debated the relevance of the abovementioned challenges as well. The most crucial element discussed pertains to the need to centralize the information in a structured and standardized way. Participants highlighted that such data must be standardized (to allow comparison and integration), reliable (to avoid misinterpretation of the outcomes), frequent (to be timely and effective in supporting decision makers), and structured (to avoid connection problems among different systems).

The challenges were mainly confirmed by the focus group, and thus the debate was mainly devoted to overcoming them. The main solution proposed was sharing data through a common platform managed by an independent third party: this tool would solve the problems related to information sharing, would increase the standardization of data, and finally would solve issues about confidentiality.

Second, the group mentioned several times the importance of clearly demonstrating to all the stakeholders, but especially to buyers, the value of data sharing for them. This is consistent with the indications of the stakeholder theory. In fact, if focal companies are not willing to share their data, regardless of the value for the suppliers or for the other stakeholders, the system cannot work.

Finally, the focus group debated about the importance of having the data certified by a third party. To avoid any expropriation and misuse of such information, a third reliable party should be involved in the process as collector and facilitator, using a dedicated digital platform. This point was especially mentioned as critical, to avoid eventual risk of adverse selection by the buyer. As a matter of fact, if the buyer has negative information about a supplier, probably is not willing to share it with financial institutions, to avoid the risk to make things worse; in the same vein, if data are positive, it might be convenient to hide this information in a lucrative way. Without an external entity that provides a guarantee for data integrity and validity, buyers should take care of this, but it is quite clear that buyers are not willing to have this additional responsibility. At the same time, without any audit procedure (as is used for the financial data) a rating agency would be ill-advised to rely heavily on operational data provided by buyers. In this vein, to mitigate the challenge, the importance of considering data about strategic suppliers appeared as a key point again.

According to previous insights, the conceptual framework in the block of challenges was revised, as depicted in Figure 6. 


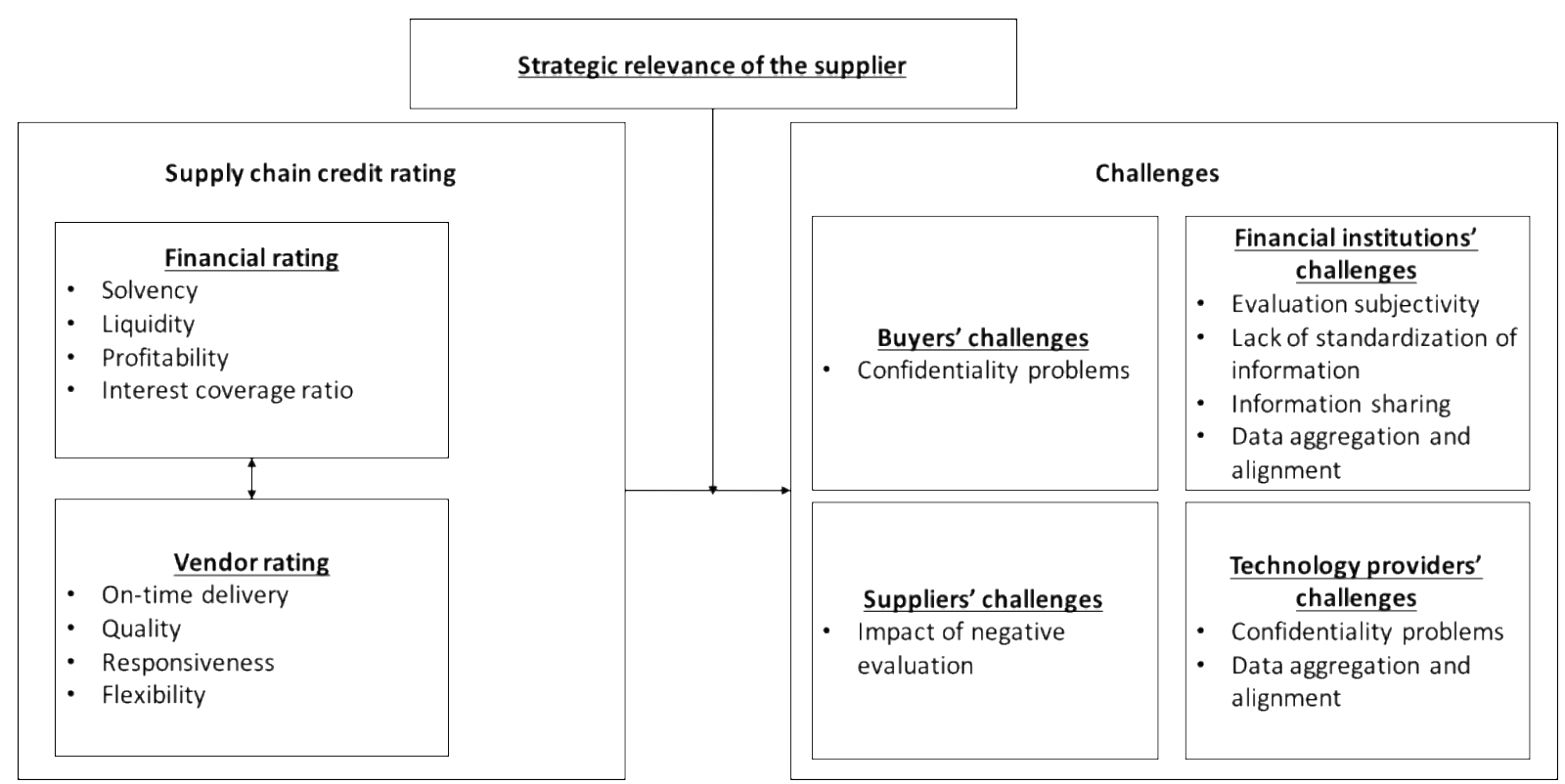

Figure 6: Challenges of the supply chain credit rating

\section{Discussion}

The goal of the final focus group was the presentation of the two frameworks reported in Figures 5 and 6 to gather the experts' opinions.

The focus group agreed that the frameworks are a good representation of the current state of the art of the problem, highlighting a clear link among the variables and the roles of the different actors. The iterative sharing of the models among stakeholders of different groups as well as considering the same stakeholders in different moments allowed us to achieve a high level of agreement in the final version of the framework. The possibility to involve heterogeneous stakeholders in each group allowed the development of a quite exhaustive framework. In particular, participants confirmed the moderating effect of the strategic relevance of the supplier in the relationship between supply chain credit rating and the achievement of the benefits and the mitigation of the challenges: this confirms the need for descriptive data in addition to financial and vendor rating data. Furthermore, they considered the strategic relevance of the supplier as representative of all the descriptive variables discussed (e.g., the number of suppliers, the interchangeability of the suppliers, relationship duration). Moreover, they confirmed that some of the initial variables of the supply chain rating, such as innovation and sustainability, are relevant in terms of vendor rating but not as much when it comes to a supply chain credit rating.

A key point addressed by the focus group was the importance to manage the information gathering, elaboration, analysis, and interpretation simultaneously involving all the relevant stakeholders. The current way of managing most of the financial data is per single company, without any information sharing or supply chain collaboration approach. The supply chain finance literature, however, is rich with contributions showing that the collaborative management of working capital, by combining and sharing data among different stakeholders, might generate shared benefits (Protopappa-Sieke and Seifert, 2017) as well as reduce the cost for the whole supply chain (Viskari and Karri, 2012). Our results are consistent with this line of research. In fact, our results confirm that without a holistic approach and without the support of all the stakeholders, with their different benefits and different challenges, some potential benefits and ways to overcome the challenges could be missed. In fact, this consideration might be both an opportunity and a problem to implement a supply chain credit rating. It is an opportunity because an extended vision along the supply chain is necessary to implement this 
approach, with an in-depth involvement and commitment by all the stakeholders. This view is a prerequisite, as in the case of the implementation of SCF solutions. On the other hand, if a single stakeholder is not willing to collaborate, the overall idea might be difficult to implement.

The focus group discussion leads us to confirm, in the case of financial risks and in particular of supply chain credit risk, the relevance of the network position and influence (Harland et al., 2003) and of the essential need for proper information management and information sharing (Tang, 2006).

In fact, a supply chain credit rating system could rely on, or at least communicate with, currently existing systems. Therefore, it can act as a collector of information from different proprietary platforms, opening new business opportunities for all the involved parties, as highlighted also during the case studies. At the same time, it can also prevent the acceptance of underestimated risks, in particular in the case of lending from financial institutions to operationally distressed companies, which they could better detect.

Finally, discussing the model within the last focus group helped us in confirming the perceived challenges as well as the benefits of such an integrated model by different stakeholders. In fact, these insights are just perceived in the current stage given that the model has not been applied yet. Some of the senior managers involved in the meeting were particularly concerned about cultural resistance inside the company, at top management level. On one hand, managers and board members could be concerned about confidentiality, data leaks, and business and legal implications. On the other hand, the possible implementation of IT connections with other companies, even through application program interfaces (APIs), or the storage of data in cloud systems, might increase the perception of vulnerability of the company as well as several reputational concerns.

For this reason, the focus group again stressed the importance of having a third reliable party involved to represent all the stakeholders' interests, avoiding possible misappropriation and misuse of the information collected and guaranteeing the correctness, the accuracy, and the timeliness of the data. In addition, some interesting emerging IT solutions can support the information management, sharing, and control, as is the case of the blockchain.

\section{Conclusions and future developments}

The goal of this paper was to investigate the possibility of developing an innovative approach to credit rating, by combining the traditional financial rating performed by financial institutions with the vendor rating (adopted by buyers to monitor their suppliers) into a supply chain credit rating.

We pursued this goal by means of a twofold methodology, consisting of both multiple case studies and multiple focus groups.

Through the empirical analysis, we were able to show that vendor rating (i.e., on-time delivery, quality, responsiveness, flexibility), performed by buyers regarding their strategic suppliers, have great potential value if combined with financial data, to develop a better credit rating. We have also highlighted the benefits expected for all the stakeholders involved (buyers, suppliers, financial institutions, and technology providers), and finally the challenges they face. By discussing our results, we have been able to formulate research propositions that summarize the main findings and will allow the development of a supply chain credit rating, as well as further research on the topic, e.g. by testing such propositions in future studies. 
We believe that our findings provide significant contributions to both research and practice, as well as present several limitations and open up new research directions, described in following paragraphs.

\section{Research contributions}

Considering the research contributions, first we have provided an initial answer to a major question that is debated in the literature: how can the credit rating adopted by the financial system be improved, in particular for small and medium companies, for which the standard financial information is less available and reliable (Lehman, 2003)? By complementing the limited and backward-looking financial information with rich and timely operational information, all the stakeholders involved (buyer, suppliers, financial institutions, and technology providers) could obtain a more accurate credit rating, with better predictive power.

Second, the literature is also in support of the notion that supply risk is a major concern for buyers, and one of the major risk sources is supplier bankruptcy (Harland et al., 2003; Zsidisin, 2003). This means that suppliers, in particular strategic ones, are at the same time a key asset for focal companies, as well as a major risk source. This risk was further increased by the consequences of the 2008 financial crisis. We have shown how a supply chain credit rating would be highly beneficial for both buyers and their strategic suppliers, as it would allow better risk assessment and better risk mitigation, offering the possibility to facilitate access to more credit at a lower cost. This would mean shifting the trade-off between the benefits and the risk of tight strategic supply chain relationships. Indeed, close, long-term relationships with key partners would not mean higher risk, but rather lower risk, given the possibility to establish a virtuous circle between operational and financial performance.

Third, adopting a stakeholder theory perspective, by considering all the relevant stakeholders involved in the deployment of a supply chain credit rating, we have shown that all parties would gain relevant benefits, of different kinds, and, therefore, there are significant incentives to proceed in this direction. This also contributes to a new area of application for this theoretical background. At the same time, we have also shown the relevant challenges to be faced and overcome, as well as the possible solutions to mitigate such challenges. This contributes to the debate about the possibility of establishing a collaborative and open approach among companies, not only within the same supply chain, but also involving financial institutions and technology providers, thus enlarging the scope.

Finally, our framework contributes to two streams of literature, financial and vendor rating: in fact, these two streams of literature are mainly independent and an integration of the two views is one of the major innovative contributions of our work. Moreover, our framework contributes to stakeholder theory, by proposing a new field of application that combines a variety of heterogeneous stakeholders. Stakeholder theory affirms that a manager willing to consider all the relevant stakeholders might be stuck and unable to make decisions for the large number of trade-offs existing among stakeholders. This model supports the theory by illustrating both benefits and challenges for all the stakeholders, but also provides suggestions for mitigating challenges, thus solving trade-offs among stakeholders.

\section{Managerial contributions}

Moving to managerial contributions, they are actually very relevant and aligned with the research ones. In this case as well, possible contributions are identified for all the stakeholders involved.

For industrial companies, the paper provides a new model to evaluate supply chain partners in a more reliable way. For suppliers, the model might be an opportunity to present themselves either to financial institutions or to buyers integrating different sources of information and 
making a more reliable presentation of themselves. Results of the paper might also convince buyers to share their data with third parties, improving the possibility for suppliers to have access to credit.

For buyers, the proposed model has important benefits to improve their risk assessment capabilities and to provide better financial support to strategic suppliers. As the cases summarized, buyers might implement an internal supply chain credit rating, that timely detects areas of risks in the supply chain and implement risk mitigation strategies. This contribution is so strong that some buyers with a high level of internal liquidity might decide to create a spinoff to launch their own financial institution, lending money to their suppliers through reverse factoring and taking full advantage of the visibility of these data. Other companies might adopt a similar approach through the implementation of other supply chain finance solutions, such as dynamic discounting (Gelsomino et al., 2016b), thereby improving the liquidity along the supply chain without involving the financial institution anymore.

This model might also support buyers in revising their vendor rating model, through the combination of financial and supply chain data. Buyers are now used to collect these data among different company departments or buying financial information through third parties: if a supply chain credit rating model would be used in the whole company, the processes to perform vendor rating would become smoother and less expensive for the company itself.

On the financial institution side, their need to improve the accuracy of their ratings, in particular for SMEs, is a practical issue, which affects their business development and risk management activities. After many years of quantitative easing, when money has been poured into the financial system, many SMEs still struggle to obtain funding. This is because financial institutions are subject to stricter Basel requirements and cannot take uncontrolled risk with SMEs. Therefore, they are not exploiting the available cash in full, while with a supply chain credit rating they could better assess the risk of SMEs, thanks to the additional information provided by their large buyers, and therefore develop their business. Results of the paper might help financial institutions in knowing the most important vendor rating data to incorporate into a supply chain credit rating, thus developing a more accurate model for the probability of default. Results of the paper also give a practical overview about main challenges and opportunities for all the actors involved: financial institutions indeed could ward off these challenges and exploit these benefits to involve the other actors.

Finally, on the technology provider side, the model offers a potential tool to support their value proposition. These actors see a very good opportunity to develop their business by offering an innovative solution that leverages on their existing role, building even closer relationships with their customers and opening up a new market. Through the model, they have a useful tool, to demonstrate to potential buyers the value of an integrated platform or to add additional services into their offering. Moreover, services offered by technology providers might also be very helpful to mitigate the main challenges of this model, thus strengthening the relationship with their customers. Technology providers might use the opportunity to offer algorithms to compute the supply chain credit rating, thereby extending their offering to both the physical and the financial supply chain.

\section{Limitations and future research}

The paper is case-based and so we were able to formulate some research propositions but not to validate them, through a statistical sample. The natural development of our work would be to further elaborate upon such propositions and empirically test them. In this way, it would be possible to confirm and enrich our contribution. 
A second limitation of the paper pertains to the fact that we did not interview directly suppliers. Further development of the study might focus on suppliers' perspective, to validate benefits and challenges with their perspective as well.

Third, the paper focuses just on the European area, that is under Basel requirements. A comparison with other continents and with other regulations about credit scoring might be helpful to highlight similarities and differences and to address the result generalizability,

In addition, the paper does not consider any specific contingent variables. The cases highlighted the importance of the strategic relevance of the supplier and several times the focus on small suppliers was considered, but the actual impact of these contingent elements or other contingent variables (e.g., industry, country of origin, etc.) was not taken into account. In the same vein, the paper proposes a model to use within companies and supply chains, without considering potential implications for processes and organization. Further development of the present study might look at the implementation phase, evaluating implications at the internal level.

Finally, what is probably the greatest limitation of our work, and surely a very interesting direction for future development, is the lack of empirical testing of the benefit of a combined adoption of financial and vendor rating data to improve credit rating accuracy. Despite the fact that we have found strong agreement among all stakeholders about this, as well as some anecdotal evidence supporting it, there is the need for a large-scale empirical test to estimate the default probability in a more accurate way. This will require both financial and operational data to be gathered from a significant sample of companies, including both good and bad performing ones, both surviving and defaulted ones. This purpose could be achieved by extending the model suggested by Lind et al. (2012) for the automotive industry to this new area of application, considering not only financial variables but also operational ones. In this way, it would be possible to demonstrate the benefits of combining the two sets of information and to compare such benefits with the costs of gathering and sharing the required data.

\section{References}

Altman, E. I., \& Rijken, H. A. 2004. How rating agencies achieve rating stability. Journal of Banking \& Finance, 28(11), 2679-2714.

Altman, Edward I. 1968. Financial ratios, discriminant analysis and the prediction of corporate bankruptcy. The Journal of Finance 23 (4): 589-609.

Altman, Edward I., Young Ho Eom, and Dong Won Kim. 1995. Failure prediction: Evidence from korea. Journal of International Financial Management \& Accounting 6 (3): 230-49.

Asmundson, I. et al., 2011. Trade Finance in the 2008-09 Financial Crisis: Evidence from IMF and BAFT-IFSA Surveys of Banks. In Washington, DC: The World Bank.

Baklanova, V., 2009. Regulatory Use of Credit Ratings: How It Impacts the Behavior of Market Constituents. International Finance Review 10, 65-104.

Basel Committee on Bank Supervision, 2001. The Internal Ratings-Based Approach.

Basel Committee on Bank Supervision, 2004. Basel II: International Convergence of Capital Measurement and Capital Standards: a Revised Framework.

Bendig, D., Strese, S., \& Brettel, M., 2017. The link between operational leanness and credit ratings. Journal of Operations Management, 52, 46-55.

Bhatia, U. 1988. Predicting corporate sickness in india. Studies in Banking \& Finance 7 : 57-71.

BIS, 2011. Basel III: A global regulatory framework for more resilient banks and banking systems,

Boissay, F. \& Gropp, R., 2007. Trade Credit Defaults and Liquidity Provision by Firms, Rochester, NY. Available at: http://papers.ssrn.com/abstract=985123 [Accessed September 7, 2015].

Brunner, A., Pieter, J., \& Weber, M. 2000. Information production in credit relationship: On the role of internal ratings in commercial banking (No. 2000/10). CFS Working Paper.

Busse, C., Meinlschmidt, J., \& Foerstl, K. 2017a. Managing Information Processing Needs in Global Supply Chains: A Prerequisite to Sustainable Supply Chain Management. Journal of Supply Chain Management, 53(1), 87-113.

Busse, Christian; Martin C. Schleper, Jenny Weilenmann, Stephan M. Wagner. 2017b. Extending the supply chain visibility boundary: Utilizing stakeholders for identifying supply chain sustainability risks. International Journal of Physical Distribution \& Logistics Management, Vol. 47 Issue: 1,pp. 18-40, doi: 10.1108/IJPDLM-02-2015-0043 
Caniato, Federico; Luca Mattia Gelsomino, Alessandro Perego, Stefano Ronchi. 2016. Does finance solve the supply chain financing problem?. Supply Chain Management: An International Journal, Vol. 21 Issue: 5,pp. 534-549, doi: 10.1108/ SCM-11-2015-0436

Carter, J.R. \& Narasimhan, R., 1996. Purchasing and Supply Management: Future Directions and Trends. International Journal of Purchasing and Materials Management, 32(3), pp.2-12

Carter, J.R. et al., 2010. Impact of culture on supplier selection decision making. The International Journal of Logistics Management, 21(3), 353-374.

Chava, S., \& Purnanandam, A., 2011. The effect of banking crisis on bank-dependent borrowers. Journal of Financial Economics, 99(1), 116-135.

Chen, X. \& Hu, C., 2011. The Value of Supply Chain Finance. In InTech, Published, pp. 111-132.

Crouhy, M., Galai, D., \& Mark, R. 2001. Prototype risk rating system. Journal of banking \& finance, 25(1), 47-95.

D. Simchi-Levi, P. Kaminsky, E. Simchi-Levi, 2000. Designing and Managing the Supply Chain, McGraw Hill, Boston.

Donaldson, T., \& Preston, L. E. 1995. The stakeholder theory of the corporation: Concepts, evidence, and implications. Academy of management Review, 20(1), 65-91.

Edwards, B. 1997, Credit Management Handbook, 4th ed., Gower Publishing, Hampshire.

Eisenhardt, Kathleen. 1989. Building theories from case study research. The Academy of Management Review 14 (4): 532-50.

English, W. B., \& Nelson, W. R. 1998. Bank Risk rating of business loan. Board of Governors of the Federal Reserve System FEDS Paper, (98-51).

ESMA, 2015. European Securities and Markets Authority - Statistics - Rating activity.

Freeman, R. E., Harrison, J. S., Wicks, A. C., Parmar, B. L., \& De Colle, S. 2010. Stakeholder theory: The state of the art. Cambridge University Press.

Gelsomino, L. M., Mangiaracina, R., Perego, A., \& Tumino, A. 2016a. Supply chain finance: a literature review. International Journal of Physical Distribution \& Logistics Management, 46(4), 348-366.

Gelsomino, L. M., Mangiaracina, R., Perego, A., \& Tumino, A. 2016b. Supply Chain Finance: Modelling a Dynamic Discounting Programme. Journal of Advanced Management Science Vol, 4(4).

Gibson, H. D., Hall, S. G., \& Tavlas, G. 2014. Doom-loops: The Role of Rating Agencies in the Euro Financial Crisis (No. 14/16).

Gioia, D. A., Corley, K. G., \& Hamilton, A. L. 2013. Seeking qualitative rigor in inductive research: Notes on the Gioia methodology. Organizational Research Methods, 16(1), 15-31.

Goldman, A. E. 1962. The group depth interview. The Journal of Marketing, 61-68.

Gomm, Moritz Leon. 2010. Supply chain finance: applying finance theory to supply chain management to enhance finance in supply chains, International Journal of Logistics Research and Applications, 13:2, 133-142

Grunert, J., Norden, L., \& Weber, M. 2005. The role of non-financial factors in internal credit ratings. Journal of Banking \& Finance, 29(2), 509-531.

Harland, C., Brenchley, R., \& Walker, H. 2003. Risk in supply networks. Journal of Purchasing and Supply management, 9(2), 51-62.

Heugens, P., van den Bosch, F., \& van Riel, C. 2002. Stakeholder integration: Building mutually enforcing relationships. Business \& Society, 41(1): 36-60.

Ho, W., Xu, X. \& Dey, P.K., 2010. Multi-criteria decision making approaches for supplier evaluation and selection: A literature review. European Journal of Operational Research, 202(1), pp.16-24.

Hofmann, E., 2005. Supply Chain Finance: some conceptual insights. Logistik Management. Innovative Logistikkonzepte. Wiesbaden: Deutscher Universitäts-Verlag, pp.203-214.

Huang, S.H. \& Keskar, H., 2007. Comprehensive and configurable metrics for supplier selection. International Journal of Production Economics, 105(2), pp.510-523.

Huang, Zan, Hsinchun Chen, Chia-Jung Hsu, Wun-Hwa Chen, and Soushan Wu. 2004. Credit rating analysis with support vector machines and neural networks: A market comparative study. Decision Support Systems 37 (4): $543-58$.

Humphreys, P. et al., 2007. Integrating design metrics within the early supplier selection process. Journal of Purchasing and Supply Management, 13(1), pp.42-52.

Humphreys, Paul, Ronan McIvor, and Felix Chan. 2003. Using case-based reasoning to evaluate supplier environmental management performance. Expert Systems with Applications 25 (2): 141-53.

Ivashina, V. \& Scharfstein, D., 2010. Bank lending during the financial crisis of 2008. Journal of Financial Economics, 97(3), pp.319-338.

Izan, HY. 1984. Corporate distress in australia. Journal of Banking \& Finance 8 (2): 303 - 20.

Jacobson, T., Lindé, J., \& Roszbach, K. 2006. Internal ratings systems, implied credit risk and the consistency of banks' risk classification policies. Journal of Banking \& Finance, 30(7), 1899-1926.

Jones, T. M. 1995. Instrumental stakeholder theory: A synthesis of ethics and economics. Academy of management review, 20(2), 404-437.

Jüttner, Uta; Helen Peck \& Martin Christopher. 2003. Supply chain risk management: outlining an agenda for future research, International Journal of Logistics Research and Applications, 6:4, 197-210

Kenjegaliev, A., Duygun, M., \& Mamedshakhova, D. 2016. Do rating grades convey important information: German evidence?. Economic Modelling, 53, 334-344. 
Khan, M., Hussain, M., \& Saber, H. M. 2016. Information sharing in a sustainable supply chain. International Journal of Production Economics, 181, 208-214.

Klapper, L.F. \& Randall, D., 2011. Financial Crisis and Supply-Chain Financing. Trade Finance during the Great Trade Collapse, p.73.

Korpela, J., Lehmusvaara, A., \& Tuominen, M. 2001. An analytic approach to supply chain development. International Journal of Production Economics, 71(1), 145-155.

Lambert, Douglas M., Martha C. Cooper, and Janus D. Pagh. 1998. Supply chain management: Implementation issues and research opportunities. The International Journal of Logistics Management 9 (2): 1-20.

Lamoureux, J.-F. \& Evans, T.A., 2011. Supply Chain Finance: A New Means to Support the Competitiveness and Resilience of Global Value Chains, Rochester, NY: Social Science Research Network.

Laplume, A. O., Sonpar, K., \& Litz, R. A. 2008. Stakeholder theory: Reviewing a theory that moves us. Journal of management, 34(6), 1152-1189.

Lasch, R. \& Janker, C.G., 2013. Supplier selection and controlling using multivariate analysis. International Journal of Physical Distribution \& Logistics Management.

Lehmann, Bina. 2003. Is it worth the while? the relevance of qualitative information in credit rating. The Relevance of Qualitative Information in Credit Rating (April 17, 2003). EFMA.

Lind, L., Pirttilä, M., Viskari, S., Schupp, F., \& Kärri, T. 2012. Working capital management in the automotive industry: Financial value chain analysis. Journal of purchasing and supply management, 18(2), 92-100.

Luzzini, D., Caniato, F. \& Spina, G., 2014. Designing vendor evaluation systems: An empirical analysis. Journal of Purchasing and Supply Management, 20(2), pp.113-129.

Maestrini, V., Luzzini, D., Maccarrone, P., \& Caniato, F. (2017) "Supply chain performance measurement systems: A systematic review and research agenda", International Journal of Production Economics, Vol. 183, pp. 299-315.

Manuj, I., \& Mentzer, J. T. 2008. Global supply chain risk management. Journal of business logistics, 29(1), 133-155.

Meulbrook, L., 2000. Total strategies for company-wide risk control. Financial Times, May 9.

Meyer, J. W., \& Rowan, B. 1977. Institutionalized organizations: Formal structure as myth and ceremony. American Journal of Sociology, 83(2): 340-462.

Morgan, D. L. 1996. Focus groups. Annual review of sociology, 22(1), 129-152.

Narasimhan, R., \& Talluri, S. 2009. Perspectives on risk management in supply chains.

$\mathrm{Ng}$, W.L., 2008. An efficient and simple model for multiple criteria supplier selection problem. European Journal of Operational Research, 186(3), pp.1059-1067.

Niklis, D., Doumpos, M., \& Zopounidis, C. (2014). Combining market and accounting-based models for credit scoring using a classification scheme based on support vector machines. Applied Mathematics and Computation, 234, 69-81.

Parthiban, P., Zubar, H.A. \& Katakar, P., 2013. Vendor selection problem: a multi-criteria approach based on strategic decisions. International Journal of Production Research, 51(5), pp.1535-1548.

Partnoy, F., 1999. The Siskel and Ebert of financial markets: two thumbs down for the credit rating agencies. Washington University Law Quarterly 77, 619-712.

Pettit, T. J., Croxton, K. L., \& Fiksel, J. 2013. Ensuring supply chain resilience: development and implementation of an assessment tool. Journal of Business Logistics, 34(1), 46-76.

Pettit, T. J., Fiksel, J., \& Croxton, K. L. 2010. Ensuring supply chain resilience: development of a conceptual framework. Journal of business logistics, 31(1), 1-21.

Pfohl, H.C. \& Gomm, M., 2009. Supply chain finance: optimizing financial flows in supply chains. Logistics Research, 1(3), pp.149-161.

Phillips, R., Freeman, R. E., \& Wicks, A. C. 2003. What stakeholder theory is not. Business ethics quarterly, 13(04), 479-502.

Protopappa-Sieke, M., \& Seifert, R. W. 2017. Benefits of working capital sharing in supply chains. Journal of the Operational Research Society, 68(5), 521-532.

Punniyamoorthy, M., Mathiyalagan, P. \& Parthiban, P., 2011. A strategic model using structural equation modeling and fuzzy logic in supplier selection. Expert Systems with Applications, 38(1), pp.458-474.

Purda, L. D., 2011. Assessing credit or determining quantity? the evolving role of rating agencies. Journal of Applied Finance 21(2), 20.

Raddatz, C., 2010. Credit Chains and Sectoral Comovement: Does the Use of Trade Credit Amplify Sectoral Shocks? The Review of Economics and Statistics, 92(4), pp.985-1003.

Rubin, H. J., \& Rubin, I. S. (2011). Qualitative interviewing: The art of hearing data. Sage.

Schmidt, G. and Wilhelm, W. E. (2000). Strategic, tactical and operational decisions in multi-national logistics networks: a review and discussion of modeling issues. International Journal of Production Research, 38 (7):1501 - 1523.

Sharland, A., Eltantawy, R.A. \& Giunipero, L.C., 2003. The Impact of Cycle Time on Supplier Selection and Subsequent Performance Outcomes. The Journal of Supply Chain Management, 39(3), pp.4-12.

Sivakumar, R., Kannan, D. \& Murugesan, P., 2015. Green vendor evaluation and selection using AHP and Taguchi loss functions in production outsourcing in mining industry. Resources Policy, 46, pp.64-75.

Stainer, A., \& Stainer, L. (1998). Business performance-a stakeholder approach. International Journal of Business Performance Management, 1(1), 2-12.

$\mathrm{Su}, \mathrm{Y}$., Lu, N., 2015. Supply chain finance credit risk evaluation method based on self-adaption weight. Journal of computer and communications 3, 13-21. 
Suchman, M. C. 1995. Managing legitimacy: Strategic and institutional approaches. Academy of Management Review, 20(3): 571-610.

Talluri, S., 2002. A buyer-seller game model for selection and negotiation of purchasing bids. European Journal of Operational Research, 143(1), pp.171-180.

Tang, C. S. 2006. Perspectives in supply chain risk management. International Journal of Production Economics, 103(2), 451-488.

Tang, O., \& Musa, S. N. 2011. Identifying risk issues and research advancements in supply chain risk management. International journal of production economics, 133(1), 25-34.

Tantalo, C., \& Priem, R. L. 2016. Value creation through stakeholder synergy. Strategic Management Journal, 37(2), 314-329.

Treacy, W. F., \& Carey, M. 2000. Credit risk rating systems at large US banks. Journal of Banking \& Finance, 24(1), 167-201.

Tuncel, G., \& Alpan, G. 2010. Risk assessment and management for supply chain networks: A case study. Computers in industry, 61(3), 250-259.

Vaaland, Terje I.; Morten Heide, 2007. Can the SME survive the supply chain challenges?. Supply Chain Management: An International Journal, Vol. 12 Issue: 1,pp. 20-31, doi: 10.1108/13598540710724374

Van Maanen, J. 1979. The fact of fiction in organizational ethnography. Administrative Science Quarterly, 24, 539-550. Viskari, S., \& Kärri, T. 2012. A model for working capital management in the inter-organisational context. International Journal of Integrated Supply Management, 7(1-3), 61-79.

Wang, Q., 2010. The credit risk evaluation of supply chain finance based on decision tree. New Finance 4, 38-41.

Weber, C.A., Current, J.R. \& Benton, W.C., 1991. Vendor selection criteria and methods. European Journal of Operational Research, 50(1), pp.2-18.

White, L. J. 2010. Markets: The credit rating agencies. The Journal of Economic Perspectives, 24(2), 211-226.

Wilson, E.J., 1994. The Relative Importance of Supplier Selection Criteria: A Review and Update. International Journal of Purchasing and Materials Management, 30(2), pp.34-41.

Wood, O.G., 1981. Commercial Banking: Practice and Policy, Van Nostrand, New York, NY.

Wuttke, D.A., Blome, C. \& Henke, M., 2013. Focusing the financial flow of supply chains: An empirical investigation of financial supply chain management. International Journal of Production Economics, 145(2), pp.773-789.

Zhao, X., Xie, J., Zhang, W., 2002. The impact of information sharing and ordering co-ordination on supply chain performance. Supply Chain Manag.: Int. J. 7, 24-40.

Zhao, X., Yeung, K., Huang, Q., Song, X., 2015. Improving the predictability of business failure of supply chain finance clients by using external big dataset. Industrial Management \& Data 115(9), 1683-1703.

Zsidisin, G. A. 2003. A grounded definition of supply risk. Journal of Purchasing and Supply Management, 9(5), $217-$ 224. 
Annex A - Variables included in the analysis

\begin{tabular}{|c|c|c|c|}
\hline Variable Group & Variable Item & Description & References \\
\hline \multirow{4}{*}{ Financial rating } & Solvency & $\begin{array}{l}\text { Represents the ability of } \\
\text { companies to pay their debts } \\
\text { as well as the relevance of } \\
\text { debts for the companies }\end{array}$ & $\begin{array}{l}\text { Niklis et al., 2014; } \\
\text { Huang et al., } 2003\end{array}$ \\
\hline & Liquidity & $\begin{array}{l}\text { Represents the level of liquid } \\
\text { assets of a company in the } \\
\text { short- and long-term } \\
\text { perspectives }\end{array}$ & $\begin{array}{l}\text { Altman, 1968; Bhatia, } \\
1988\end{array}$ \\
\hline & Profitability & $\begin{array}{l}\text { Measures the level of } \\
\text { company profitability } \\
\text { considering money invested } \\
\text { by the stakeholders (ROE), the } \\
\text { efficient use of asset (ROA), } \\
\text { and cumulative profitability } \\
\text { over time }\end{array}$ & $\begin{array}{l}\text { Altman, 1968; Altman } \\
\text { et al., } 1995\end{array}$ \\
\hline & $\begin{array}{l}\text { Interest } \\
\text { coverage ratio }\end{array}$ & $\begin{array}{l}\text { Measures the capability of a } \\
\text { company to pay interests on } \\
\text { outstanding debt }\end{array}$ & Izan, 1984 \\
\hline \multirow{6}{*}{ Vendor rating } & Cost & $\begin{array}{l}\text { Per unit net purchase cost } \\
\text { from a supplier }\end{array}$ & \multirow{6}{*}{$\begin{array}{l}\text { Caniato et al., 2014; } \\
\text { Lasch and Janker, } \\
\text { 2013; Sharland et al., } \\
2003\end{array}$} \\
\hline & Time & $\begin{array}{l}\text { Includes time-related } \\
\text { performance, such as the } \\
\text { delivery lead time and on-time } \\
\text { deliveries by the supplier }\end{array}$ & \\
\hline & Quality & $\begin{array}{l}\text { Includes quality related } \\
\text { performance of the supplier, } \\
\text { such as the conformity to } \\
\text { requirements and the absence } \\
\text { of defects }\end{array}$ & \\
\hline & Flexibility & $\begin{array}{l}\text { Capability of the supplier to } \\
\text { rapidly respond to a request } \\
\text { for changes in terms of } \\
\text { volume, mix, or time }\end{array}$ & \\
\hline & Innovation & $\begin{array}{l}\text { Capability of the supplier to } \\
\text { offer innovative products, } \\
\text { processes, or services }\end{array}$ & \\
\hline & Sustainability & $\begin{array}{l}\text { Capability of the supplier to } \\
\text { offer environmentally and } \\
\text { socially sustainable products } \\
\text { or processes }\end{array}$ & \\
\hline
\end{tabular}

Annex B - Case study protocol

\section{Case study protocol for the financial institution}

1. General information about the financial institution

2. Analysis of the current model adopted to define the financial rating?

$\circ$ How is the creditworthiness evaluation process structured?

- Which are the main phases?

- Which is the goal and the purpose of each phase?

- Which is the duration of each phase? 
- Which are the main actors involved in the creditworthiness evaluation process?

- Which are the models adopted in the creditworthiness evaluation process?

- Which are the financial variables used in the creditworthiness evaluation?

- Do you use any qualitative variables? If yes, which are the "qualitative" variables included in the evaluation? And which is the weight of these "qualitative" information?

○ How do you evaluate the current model of evaluation?

- Which are the main costs you see?

- Which are the main benefits you see?

- Which are the main pros and cons of the current model?

3. Can operative variables such as vendor rating ones improve the financial rating system reliability and effectiveness?

- Have you ever evaluated these kinds of variables? If yes, could you please said to us which kinds of evaluation and which kind of data you have considered?

- What would be the benefits coming from the adoption of such model (integrated with qualitative information)?

- What would be the costs coming from the adoption of such model?

- What would be the possible challenges?

○ Do you see any potential value/challenge for supply chain companies?

○ Do you see any potential value/challenge for the financial institution?

- Do you see any potential value/challenge for the technology providers?

- Models integrated with "qualitative" variables have already been tested? If yes, what were the benefits and costs observed?

- Do you know whether some other financial institution had already considered these kind of models? If yes, with which benefits and under which challenges?

\section{Case study protocol for the buyers}

1. General information about the buyer

2. Could you please describe your current model of vendor rating adopted by the buyer?

- Which variables are you considering?

- How often do you evaluate vendor rating performance of your suppliers?

- Which suppliers are evaluated (product categories, dimensions, level of relevance, etc.)?

- Which departments are involved in the definition of the vendor rating?

3. Do you consider also financial performance jointly with your operational performance?

$\circ$ Which kind of financial data are you considering?

- Why did you decide to merge the two views? What is the different type of information you could get through the joint management of financial and vendor rating data?

- Who is involved in that process?

- Which is the value of integration of the two views?

- Which are the challenges and costs of the integration of the two views?

○ Do you see any potential value/challenge for suppliers?

- Do you see any potential value/challange for the financial institution?

- Do you see any potential value/challange for the technology providers?

- How do you combine the two types of data?

4. Do you share these data with the financial institutions?

o If yes: how do you share these data? Which is the value for you? Which is the value for the financial institutions? Which is the value for your suppliers? Which 
was the reaction of your suppliers in the sharing of these data with the financial institution?

- If no: have you have imagined to share these data? Do you see any values in that for you? Do you see any values in that for you? Do you see any values in that for your suppliers? Do you see any values in that for the financial institution? Are your suppliers willing to share these data with the financial institution?

\section{Case study protocol for the technology provider}

1. General information about the company

2. Could you please describe which type of data are you managing?

- Which variables are you considering?

- Which variables are mainly used by your customers?

- Do you see key differences in variables adopted by different actors?

3. Do you consider combination of vendor rating and financial performance?

$\circ$ Which kind of financial and vendor rating data are you considering?

- How did you merge the two views?

Which is the value of integration of the two views?

$\circ$ Which are the challenges and costs of the integration of the two views?

o How do you combine the two types of data?

4. Which are the actors that have access to these data?

5. Which is the value for each actor that has access to these data?

$\circ$ Which is the value for you?

- Which is the value for the bank?

- Which is the value for the buyer?

- Which is the value for your suppliers?

Annex C - Interview protocol for focus group

\section{Focus group 1}

We run a role playing asking to each part to enter into the shoes of the conterparts and used this method to run the brainstorming.

Questions to financial providers:

1. Which pieces of information you think is worth sharing with supply chain actors? Which of those pieces of information with which other actors?

2. Which pieces of information you would like to collect by other supply chain actors? Which might be the value of these data for your company?

3. Do you believe there is any value in sharing these data with financial providers? Which might be the expectable benefits according to your perspective?

4. Is it possible to integrate the system also with other actors or to use the model with a different purpose?

\section{Questions to companies:}

1. Which are the pieces of information that today financial providers do not have but that you think they might have a value in having? 
2. Which might be the value for the financial providers to get these pieces of information?

3. Which are the additional services that financial providers might offer to supply chain actors thanks to the visibility of these additional data?

4. Is it possible to integrate the system also with other actors or to use the model with a different purpose?

\section{Questions to technology providers:}

1. On the basis of your experience about data sharing along the supply chain, which data might be fruitful to share with other actors? Which data to which actor?

2. Which might be the role of the technology providers in enabling the sharing of these data? Which might be the value for the technology providers to share these pieces of information?

3. Which are the additional services that technology providers might offer to supply chain actors thanks to the visibility of these additional data?

4. Is it possible to integrate the system also with other actors or to use the model with a different purpose?

\section{Focus group 2:}

1. Which are the information that you think are relevant to include into the supply chain credit rating?

a. Are you considering vendor rating data or also qualification data?

b. Which is the contribution of these data?

c. Why financial rating are not sufficient? Which is the value added by these additional data?

d. Could these data be integrated into with financial data?

2. Do you have any example of misalignment between vendor rating and financial data?

3. What do we need to explore through in depth case studies?

\section{Focus group 3:}

1. Which are the expected benefits of a supply chain credit rating for financial providers?

2. Which are the expected benefits of a supply chain credit rating for technology providers?

3. Which are the expected benefits of a supply chain credit rating for companies?

4. Which are the expected benefits of a supply chain credit rating for suppliers?

5. What do we need to explore through in depth case studies?

\section{Focus group 4:}

1. Which are the expected challenges/costs of a supply chain credit rating for financial providers?

2. Which are the expected challenges/costs of a supply chain credit rating for technology providers? 
3. Which are the expected challenges/costs of a supply chain credit rating for companies?

4. Which are the expected challenges/costs of a supply chain credit rating for suppliers?

5. What do we need to explore through in depth case studies?

\section{Focus group 5:}

1. Which is your impression about the supply chain credit rating model?

2. Do you believe the model is a good representation of the reality at the best of your knowledge?

3. Is there any changes you think is necessary? Is there any parts you do not agree? 
Annex D - Cross-case analysis about buyers' and technology providers' ratings

\begin{tabular}{|c|c|c|c|}
\hline Company & $\begin{array}{c}\begin{array}{c}\text { Vendor rating variable } \\
\text { considered }\end{array} \\
\end{array}$ & $\begin{array}{c}\text { Financial rating variable } \\
\text { considered }\end{array}$ & Hypothesis of merge \\
\hline $\mathrm{C} 1$ & $\begin{array}{ll}- & \text { Price } \\
- & \text { On-time delivery } \\
- & \text { Flexibility } \\
- & \text { Quality } \\
- & \text { Completeness of the order } \\
- & \text { Availability to share data } \\
& \text { and documents }\end{array}$ & $\begin{array}{ll}\text { - } & \text { Probability of default } \\
- & \text { Delay in supplier } \\
\text { payment } \\
\text { - }\end{array}$ & $\begin{array}{l}\text { - Joint framework to } \\
\text { calculate the probability } \\
\text { of default considering } \\
\text { both vendor and } \\
\text { financial ratings } \\
\text { - Analysis to evaluate } \\
\text { just strategic suppliers }\end{array}$ \\
\hline $\mathrm{C} 2$ & $\begin{array}{ll}- & \text { Product and service quality } \\
\text { - } & \text { Responsiveness } \\
\text { - } & \text { Compliance } \\
\text { - } & \text { Sustainability }\end{array}$ & $\begin{array}{ll}- & \text { Solvency } \\
- & \text { Liquidity } \\
- & \text { Profitability }\end{array}$ & $\begin{array}{ll}\text { - Joint analysis of } \\
\text { product } & \text { quality, } \\
\text { financial solidity, } & \text { sustainability, and } \\
\text { service level into a } \\
\text { single KPIs } \\
\text { Integrated model } \\
\begin{array}{l}\text { adopted mainly with } \\
\text { strategic suppliers }\end{array}\end{array}$ \\
\hline $\mathrm{C} 3$ & $\begin{array}{ll}- & \text { Quality } \\
- & \text { Compliance } \\
- & \text { On-time delivery } \\
- & \text { Safety } \\
- & \text { Corporate social } \\
& \text { responsibility (CSR) }\end{array}$ & $\begin{array}{ll}- & \text { Solvency } \\
- & \text { Profitability } \\
\text { - } & \text { Ratings provided by } \\
\text { external suppliers }\end{array}$ & $\begin{array}{l}\text { Two different ratings } \\
\text { are developed and } \\
\text { compared in some } \\
\text { regular meetings for } \\
\text { strategic suppliers or for } \\
\text { high-value contracts }\end{array}$ \\
\hline $\mathrm{C} 4$ & $\begin{array}{ll}- & \text { Price } \\
- & \text { Lead time } \\
- & \text { Production capacity } \\
- & \text { Flexibility } \\
- & \text { Service level } \\
- & \text { Sustainability } \\
\end{array}$ & $\begin{array}{ll}- & \text { Solidity } \\
- & \text { Profitability } \\
- & \text { Solvability }\end{array}$ & $\begin{array}{l}\text { - For strategic suppliers, } \\
\text { they tried to develop a } \\
\text { single rating }\end{array}$ \\
\hline $\mathrm{T} 1$ & $\begin{array}{ll}- & \text { Price } \\
- & \text { On-time delivery } \\
- & \text { Quality } \\
- & \text { Flexibility } \\
- & \text { Responsiveness }\end{array}$ & - $\quad$ Not yet considered & $\begin{array}{l}\text { - Joint service to } \\
\text { integrate into the same } \\
\text { platform both vendor } \\
\text { ratings and financial } \\
\text { data collected through } \\
\text { an external provider }\end{array}$ \\
\hline $\mathrm{T} 2$ & $\begin{array}{l}\text { - Analysis of the overall } \\
\text { company } \\
\text { - Analysis of the company } \\
\text { for a specific category } \\
\text { - Analysis of the company } \\
\text { for a specific contract }\end{array}$ & $\begin{array}{llr}- & \text { Financial indexes by } \\
\text { external } & \text { providers } \\
& \text { (solvency, profitability) }\end{array}$ & $\begin{array}{l}\text { More in-depth } \\
\text { evaluation done for } \\
\text { more strategic suppliers }\end{array}$ \\
\hline $\mathrm{T} 3$ & $\begin{array}{ll}\text { - } & \text { Technology level } \\
- & \text { Flexibility } \\
- & \text { Quality } \\
- & \text { On-time delivery } \\
- & \text { Sustainability }\end{array}$ & $\begin{array}{ll}- & \text { Solvency } \\
- & \text { Profitability }\end{array}$ & $\begin{array}{l}\text { - No integration for the } \\
\text { moment }\end{array}$ \\
\hline
\end{tabular}


Annex E - Cross-case analysis of rating agencies

\begin{tabular}{|c|c|c|c|}
\hline $\begin{array}{l}\text { Financial } \\
\text { providers }\end{array}$ & Main elements considered & $\begin{array}{c}\text { New parameters } \\
\text { evaluated }\end{array}$ & $\begin{array}{c}\text { Relevance of a supply chain } \\
\text { credit rating }\end{array}$ \\
\hline $\mathrm{F} 1$ & $\begin{array}{ll}- & \text { Company record } \\
- & \text { Bad events from news } \\
- & \text { Balance-sheet data } \\
- & \text { Payment data }\end{array}$ & $\begin{array}{l}\text { Number of data } \\
\text { requests by other } \\
\text { members of the } \\
\text { supply chain }\end{array}$ & $\begin{array}{l}\text { Fundamental, especially } \\
\text { to perform an ex-ante } \\
\text { evaluation of suppliers } \\
\text { with commercial purposes }\end{array}$ \\
\hline $\mathrm{F} 2$ & $\begin{array}{ll}- & \text { Solvency data } \\
- & \text { Patrimonial data } \\
- & \text { Liquidity } \\
- & \text { Profitability }\end{array}$ & $\begin{array}{ll}\text { - } & \text { Credit default swaps } \\
\text { - } & \text { Delays in payment } \\
\text { along the supply } \\
\text { chain } \\
\text { - } \\
\text { Patents } \\
\text { - Circular economy } \\
\text { projects }\end{array}$ & $\begin{array}{l}\text { - The integration at the } \\
\text { moment is not easy to } \\
\text { implement but might } \\
\text { potentially be a good } \\
\text { value-added service for } \\
\text { the future }\end{array}$ \\
\hline F3 & $\begin{array}{ll}- & \text { Solvency data } \\
- & \text { Liquidity indicators } \\
- & \text { Cash conversion cycle } \\
- & \text { Profitability } \\
- & \text { Interest coverage ratio } \\
- & \text { Constraints on efficiency }\end{array}$ & 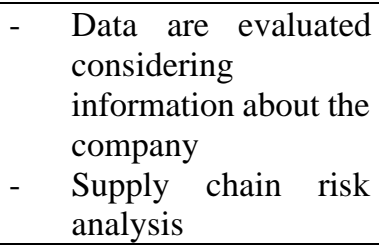 & $\begin{array}{l}\text { - Supply chain overview is } \\
\text { fundamental to have a real } \\
\text { view on the company }\end{array}$ \\
\hline
\end{tabular}


Annex F - Cross-case analysis of the expected benefits of a supply chain credit rating

\begin{tabular}{|c|c|c|c|c|}
\hline Company & Suppliers' benefits & Buyers' benefits & $\begin{array}{c}\text { Financial institutions' } \\
\text { benefits }\end{array}$ & $\begin{array}{c}\text { Technology } \\
\text { providers' benefits }\end{array}$ \\
\hline $\mathrm{C} 1$ & $\begin{array}{ll}\text { - } & \begin{array}{l}\text { Greater credit } \\
\text { access (through }\end{array} \\
\text { SCF programs) } \\
\text { - } \begin{array}{l}\text { Reduction of } \\
\text { credit cost }\end{array} \\
\text { - } & \begin{array}{l}\text { Reduction of } \\
\text { probability } \\
\text { default of }\end{array}\end{array}$ & $\begin{array}{ll}- & \text { Better assessment of } \\
& \text { supplier risk } \\
\text { - } & \begin{array}{l}\text { Stronger supplier } \\
\text { relationship }\end{array}\end{array}$ & $\begin{array}{ll}- & \text { Better assessment of } \\
\text { supplier probability } \\
\text { of default }\end{array}$ & \\
\hline $\mathrm{C} 2$ & $\begin{array}{lll}- & \text { Reduction } & \text { of } \\
\text { probability } & \text { of } \\
\text { default } & \end{array}$ & $\begin{array}{ll}\text { - } & \text { Better assessment of } \\
\text { supplier risk }\end{array}$ & $\begin{array}{ll}\text { - } & \text { Fresh information } \\
\text { about suppliers } \\
\text { - } & \text { Better assessment of } \\
\text { supplier probability } \\
\text { of default }\end{array}$ & \\
\hline C3 & 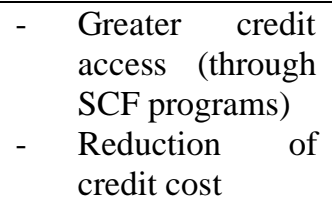 & $\begin{array}{ll}\text { - } & \text { Better information } \\
\text { about suppliers }\end{array}$ & $\begin{array}{ll}\text { - } & \text { Fresh information } \\
\text { about suppliers } \\
\text { - } & \text { Better assessment of } \\
\text { supplier probability } \\
\text { of default }\end{array}$ & \\
\hline $\mathrm{C} 4$ & & $\begin{array}{ll}\text { - } & \text { Better information } \\
\text { about suppliers }\end{array}$ & & \\
\hline $\mathrm{T} 1$ & $\begin{array}{ll}- & \begin{array}{l}\text { Reduction } \\
\text { credit cost }\end{array} \\
- & \begin{array}{l}\text { Reduction } \\
\text { probability of } \\
\text { default }\end{array} \\
- & \text { of } \\
\text { Stronger } & \\
\text { relationship with } \\
\text { buyer }\end{array}$ & $\begin{array}{lll} & \text { Stronger } & \text { supplier } \\
& \text { relationship }\end{array}$ & 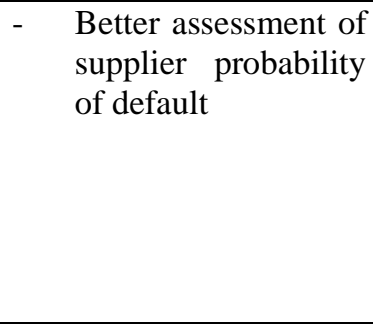 & $\begin{array}{l}\text { Long-term } \\
\text { collaboration } \\
\text { with buyers }\end{array}$ \\
\hline $\mathrm{T} 2$ & & $\begin{array}{l}\text { - } \quad \begin{array}{l}\text { Better assessment of } \\
\text { supplier risk }\end{array}\end{array}$ & & $\begin{array}{ll}\text { - } & \text { Market } \\
\text { opportunity } \\
\text { - } & \text { Long-term } \\
\text { collaboration } \\
\text { with buyers }\end{array}$ \\
\hline T3 & $\begin{array}{l}\text { - } \text { Greater credit } \\
\text { access (also for } \\
\text { small suppliers) }\end{array}$ & $\begin{array}{ll}\text { - } & \text { Better assessment of } \\
\text { supplier risk }\end{array}$ & $\begin{array}{l}\text { - More accurate } \\
\text { allocation of funds to } \\
\text { companies }\end{array}$ & $\begin{array}{ll}\text { - } & \text { Market } \\
\text { opportunity }\end{array}$ \\
\hline $\mathrm{F} 1$ & & 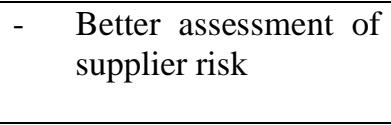 & $\begin{array}{l}\text { - } \begin{array}{l}\text { Better assessment of } \\
\text { supplier probability } \\
\text { of default }\end{array} \\
\end{array}$ & \\
\hline F2 & & $\begin{array}{ll}\text { - } & \text { Better assessment of } \\
\text { supplier risk }\end{array}$ & $\begin{array}{ll}- & \text { Better assessment of } \\
\text { supplier probability } \\
\text { of default }\end{array}$ & $\begin{array}{l}\text { Long-term } \\
\text { collaboration } \\
\text { with buyers } \\
\end{array}$ \\
\hline F3 & $\begin{array}{ll}\text { - } & \begin{array}{l}\text { Reduction } \\
\text { probability }\end{array} \\
\text { default } & \text { of } \\
& \end{array}$ & $\begin{array}{ll}\text { - } & \text { Better information } \\
\text { about suppliers } \\
\text { - } & \text { Better assessment of } \\
\text { supplier risk } \\
\text { - } \quad \begin{array}{l}\text { Stronger supplier } \\
\text { relationship }\end{array}\end{array}$ & 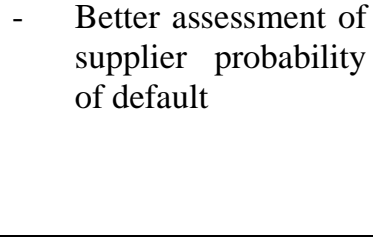 & \\
\hline
\end{tabular}


Annex G - Cross-case analysis of challenges

\begin{tabular}{|c|c|c|c|c|}
\hline Company & $\begin{array}{l}\text { Suppliers' } \\
\text { challenges }\end{array}$ & $\begin{array}{l}\text { Buyers' } \\
\text { challenges }\end{array}$ & $\begin{array}{c}\text { Financial institutions' } \\
\text { challenges }\end{array}$ & $\begin{array}{c}\text { Technology providers' } \\
\text { challenges }\end{array}$ \\
\hline $\mathrm{C} 1$ & $\begin{array}{l}\text { Risk for the } \\
\text { supplier if the } \\
\text { vendor rating } \\
\text { is not good }\end{array}$ & $\begin{array}{ll}\text { Data } \\
\text { aggregation } \\
\text { and alignment }\end{array}$ & $\begin{array}{lll}- & \text { Lack } & \text { of } \\
\text { standardization } & \text { of } \\
\text { information } & \\
\text { - } & \text { Evaluation } & \\
\text { subjectivity } & \end{array}$ & \\
\hline $\mathrm{C} 2$ & 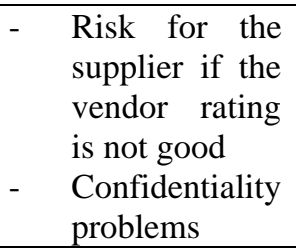 & $\begin{array}{ll}\text { - } & \text { Data } \\
\text { aggregation } \\
\text { and alignment } \\
\text { - } \quad \text { Confidentiality } \\
\text { problems }\end{array}$ & $\begin{array}{lll}- & \text { Evaluation } & \\
\text { subjectivity } & \\
\text { - } & \text { Lack } & \text { of } \\
& \text { standardization } & \text { of } \\
\text { information } & \end{array}$ & $\begin{array}{l}\text { - } \begin{array}{l}\text { Confidentiality } \\
\text { problems }\end{array} \\
\end{array}$ \\
\hline $\mathrm{C} 3$ & $\begin{array}{l}\text { Risk for the } \\
\text { supplier if the } \\
\text { vendor rating } \\
\text { is not good }\end{array}$ & $\begin{array}{ll}- & \text { Confidentiality } \\
\text { problems }\end{array}$ & $\begin{array}{lll}\text { - } & \text { Evaluation } & \\
\text { subjectivity } & \\
\text { - } & \text { Lack } & \text { of } \\
& \text { standardization } & \text { of } \\
\text { information } & \end{array}$ & $\begin{array}{l}\text { - } \begin{array}{l}\text { Confidentiality } \\
\text { problems }\end{array} \\
\end{array}$ \\
\hline $\mathrm{C} 4$ & & $\begin{array}{ll}- & \text { Confidentiality } \\
\text { problems }\end{array}$ & & $\begin{array}{ll}- & \text { Confidentiality } \\
\text { problems }\end{array}$ \\
\hline $\mathrm{T} 1$ & $\begin{array}{l}\text { Risk for the } \\
\text { supplier if the } \\
\text { vendor rating } \\
\text { is not good }\end{array}$ & $\begin{array}{l}\text { Confidentiality } \\
\text { problems }\end{array}$ & 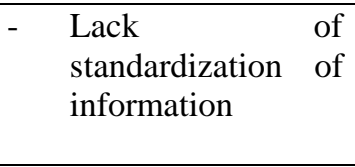 & $\begin{array}{l}\text { Data aggregation } \\
\text { and alignment }\end{array}$ \\
\hline $\mathrm{T} 2$ & & $\begin{array}{ll}\text { - } & \text { Confidentiality } \\
\text { problems } \\
\text { - } \\
\text { Data } \\
\text { aggregation } \\
\text { and alignment }\end{array}$ & $\begin{array}{ll}\text { - } & \text { Lack of } \\
\text { standardization of } & \text { of } \\
\text { information } & \\
\text { - } & \text { Information } \\
\text { sharing } & \\
\text { - Data aggregation } \\
\text { and alignment }\end{array}$ & $\begin{array}{ll}- & \text { Confidentiality } \\
& \text { problems } \\
- & \text { Information sharing } \\
- & \text { Data aggregation } \\
\text { and alignment }\end{array}$ \\
\hline $\mathrm{T} 3$ & & & $\begin{array}{ll}\text { Evaluation } \\
\text { subjectivity }\end{array}$ & \\
\hline F1 & & $\begin{array}{l}\text { - } \begin{array}{l}\text { Confidentiality } \\
\text { problems }\end{array}\end{array}$ & $\begin{array}{lll}\text { - } & \text { Lack } & \text { of } \\
\text { standardization of } & \\
\text { information } & \\
\text { - } & \text { Information } \\
\text { sharing } & \\
\text { - Data aggregation } \\
\text { and alignment }\end{array}$ & \\
\hline $\mathrm{F} 2$ & & 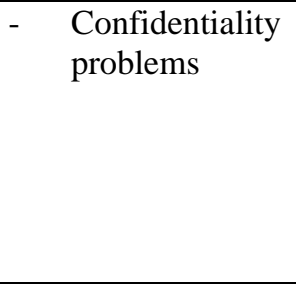 & $\begin{array}{ll}\text { - } & \text { Lack of } \\
\text { standardization of } & \text { of } \\
\text { information } & \\
\text { - } & \text { Information } \\
\text { sharing } & \\
\text { - Data aggregation } \\
\text { and alignment }\end{array}$ & \\
\hline F3 & & $\begin{array}{ll}- & \text { Confidentiality } \\
& \text { problems }\end{array}$ & $\begin{array}{ll}\text { Data aggregation } \\
\text { and alignment }\end{array}$ & $\begin{array}{ll}\text { Data aggregation } \\
\text { and alignment }\end{array}$ \\
\hline
\end{tabular}

